\title{
Brazilian coral reefs in a period of global change: A synthesis
}

\author{
Zelinda M. A. N. Leão ${ }^{1, *}$, Ruy K. P. Kikuchi', Beatrice P. Ferreira', Elizabeth G. Neves ${ }^{1}$, Hilda H. \\ Sovierzoski ${ }^{3}$, Marília D. M. Oliveira ${ }^{1}$, Mauro Maida ${ }^{2}$, Monica D. Correia ${ }^{3 \dagger}$, Rodrigo Johnsson ${ }^{1}$ \\ ${ }^{1}$ Instituto de Geociências, Universidade Federal da Bahia. \\ (Rua Barão de Jeremoabo s/n, Campus de Ondina, Ondina, 40.170-115, Salvador, Bahia, Brasil) \\ ${ }^{2}$ Departamento de Oceanografia da Universidade Federal de Pernambuco. \\ (Av. Arquitetura, s/n, Cidade Universitária - Recife - PE, CEP: 50740-550) \\ ${ }^{3}$ Universidade Federal de Alagoas, Departamento de Biodiversidade e Ecologia. Setor de Comunidades Bentônicas(LABMAR/ICBS). \\ (Rua Aristeu de Andrade, 452 - 2º andar, Farol, Maceió, Alagoas, Brasil, CEP: 57021-090) \\ ${ }^{\dagger}$ In Memorian. \\ *Corresponding author: zelinda.leao@gmail.com
}

\section{AbSTRACT}

Brazilian coral reefs form structures significantly different from the well-known reef models, as follows: (i) they have a growth form of mushroomshaped coral pinnacles called "chapeirões", (ii) they are built by a low diversity coral fauna rich in endemic species, most of them relic forms dating back to the Tertiary, and (iii) the nearshore bank reefs are surrounded by siliciclastic sediments. The reefs are distributed in the following four major sectors along the Brazilian coast: the northern, the northeastern and the eastern regions, and the oceanic islands, but certain isolated coral species can be found in warmer waters in embayments of the southern region. There are different types of bank reefs, fringing reefs, isolated "chapeirões" and an atoll present along the Brazilian coast. Corals, milleporids and coralline algae build the rigid frame of the reefs. The areas in which the major coral reefs occur correspond to regions in which nearby urban centers are experiencing accelerated growth, and tourism development is rapidly increasing. The major human effects on the reef ecosystem are mostly associated with the increased sedimentation due to the removal of the Atlantic rainforest and the discharge of industrial and urban effluents. The effects of the warming of oceanic waters that had previously affected several reef areas with high intensity coral bleaching had not shown, by the time of the 2010 event, any episodes of mass coral mortality on Brazilian reefs.

Descriptors: Coral reefs, Global changes, Coral bleaching, Endemic fauna.

\section{RESUMO}

Os recifes de coral do Brasil formam estruturas significativamente diferentes dos modelos conhecidos: (i) possuem uma forma de crescimento de pináculos coralíneos em forma de cogumelo, chamados "chapeirões", (ii) são construídos por uma fauna coralínea com baixa diversidade e rica em espécies endêmicas, sendo grande parte destas formas relíquias do período Terciário e (iii) os recifes costeiros estão num ambiente dominado por sedimentos siliciclásticos. Os recifes estão distribuídos em quatro áreas ao longo da costa brasileira: regiões norte, nordeste, leste, e nas ilhas oceânicas, mas espécies isoladas de coral podem ser encontradas em águas mais quentes nas enseadas da região sul. Diferentes tipos de banco recifais, recifes em franja, "chapeirões" isolados e um atol estão presentes ao longo da costa brasileira. Corais, milleporídeos e algas coralinas incrustantes constroem a estrutura rígida dos recifes. As áreas em que ocorrem os maiores recifes de coral correspondem às regiões nas proximidades de centros urbanos que estão experimentando crescimento acelerado e rápido desenvolvimento do turismo. Os principais efeitos antropogênicos sobre o ecossistema recifal estão associados, essencialmente ao aumento da sedimentação devido à remoção da mata atlântica e as descargas de efluentes industriais e urbanos. Os efeitos do aquecimento das águas oceânicas que vem afetando várias áreas de recifes, com alta intensidade de branqueamento de coral, não causaram mortalidade em massa nos recifes brasileiros até o evento de 2010.

Descritores: Recifes de corais, Mudanças globais, Branqueamento de coral, Fauna endêmica. 


\section{INTRODUCTION}

The reef ecosystem has been rated among the most complex and valuable of all of the marine coastal systems on Earth - along with the mangrove forests because of the varied goods and services that they supply to the adjacent coastal populations and their regional and global contributions. Among those important contributions are subsistence fishing and extraction, the tourism and recreational industries, shoreline protection and research/educational activities, and certain useful pharmaceutical products (SPURGEON, 1992; CARTÉ, 1996; CONSTANZA et al., 1997; BIRKELAND, 1997; MOBERG; FOLK, 1999; CESAR; VAN BEUKERING, 2004). Coral reefs occupy approximately $0.02 \%$ of the ocean area (SPALDING; GRENFELL, 1997), and harbor approximately $1 / 4$ of all of marine species (DAVIDSON, 1998). For centuries, populations from many tropical islands worldwide and from certain Brazilian coastal areas have depended on the coral reef resources for their sustenance and livelihoods. (SALVAT, 1992; MOBERG; RÖNNBÄCK, 2003; FERREIRA et al., 2006).

However, coral reefs are one of the ecosystems in the world most sensitive to global warming. Coral reefs are among the Earth's ecosystems most severely threatened by rising sea temperatures. Nearly all of the reefs have been heated above their maximum temperature threshold; many have already lost a significant portion of their corals, and approximately $30 \%$ to $40 \%$ of the world's coral reefs are already severely degraded (GLYNN, 1993; BROWN, 1997; WILKINSON, 2000, 2002, 2004, 2008; HUGHES et al., 2003; DONNER et al., 2005; PANDOLFI et al., 2005; HOEGH-GULDBERG, 1999; HOEGH-GULDBERG et al., 2007; WILKINSON; SOUTER, 2008; EAKIN et al., 2010; OXENFORD et al., 2010; BURT et al., 2011; DE'ATH et al., 2012; GUEST et al., 2012).

This study presents a synthesis of the Brazilian coral reefs, their major reef types, their distribution along the tropical coast, the diversity of the reef building coral fauna, the developmental history of the reefs and the major threats affecting reef diversity. Emphasis is placed on the effects of ocean warming on Brazilian coral reefs, and we contribute methods for the evaluation and mitigation of these effects.

\section{RESULTS AND DISCUSSION}

\section{MAJOR CORAL REEF TYPES AND THEIR DISTRIBUTION}

Brazilian coral reefs are one of the most prominent marine ecosystems, comprising the largest and the richest area of reefs in the entire southwestern Atlantic Ocean. These reefs are spread over 3,000 km along the Brazilian coast, from $0^{\circ} 50^{\prime} \mathrm{S}$ to $18^{\circ} 00^{\prime} \mathrm{S}$, and they can be generally divided into the following four main reef regions: the northern region, the reefs of the northeastern coast, the reefs of the eastern coast and the reef ecosystems of the oceanic islands (LEÃO et al., 2003; FERREIRA et al., 2013); however, certain coral species are also found on the southeastern and southern coasts of Brazil (CASTRO et al., 1995; MIGOTTO et al., 1999; OIGMANPSZCZOL; CREED, 2004, 2006) (Figure 1). These reefs are composed of shallow bank reefs attached to the coast, fringing reefs bordering island shores, coral knolls, patch reefs, isolated bank reefs of different forms and sizes off the coast, and coral pinnacles known as the Brazilian "chapeirões" (LEÃO et al., 2003; FERREIRA et al., 2006; RODRIGUEZRAMIREZ et al., 2008; KIKUCHI et al., 2010).

In the northern region (from $0^{\circ} 50^{\prime} \mathrm{S}$ to $5^{\circ} 00^{\prime} \mathrm{S}$ ), the most well-known reefs are those of the Parcel de Manuel Luiz on the shelf of the state of Maranhão approximately $90 \mathrm{~km}$ off its coastline. These reefs grow as giant pinnacles to depths of approximately 25 to $30 \mathrm{~m}$, and their tops reach up to 2 $\mathrm{m}$ of water depth, but during the spring low tides, some are at sea level (COURA, 1994; AMARAL et al., 2006, 2007; MAIDA; FERREIRA, 1997). Eastward from this area as far as São Roque cape, certain patch and bank reefs on the inner shelf have been mapped along the coast of the state of Ceará and the northern part of the coast of Rio Grande do Norte state (LABOREL, 1969, 1970; SANTOS et al., 2007).

The northeastern region (from approximately $5^{\circ} \mathrm{S}$ to $10^{\circ} \mathrm{S}$ ) is composed of the coastal reefs extending from the cape São Roque to the São Francisco river mouth, off the states of Rio Grande do Norte, Paraíba, Pernambuco and Alagoas. Coral reefs abound on the inner shelf. These coral reefs are mostly patch or elongated banks reefs; some are attached to the coast and others are several kilometers offshore, generally lying parallel to the coast at depths of approximately $5 \mathrm{~m}$ to 10 $\mathrm{m}$. Although not yet cored, the spatial arrangement and elongation of these reefs suggest that most of them may have grown over lines of beach rock (LABOREL, 1969; DOMINGUEZ et al., 1990; TESTA, 1997; MAIDA; FERREIRA 2003; COSTA et al. 2005; FERREIRA et al. 2006; CORREIA; SOVIERZOSKI, 2010; CORREIA, 2011) (Figures 2 and 3). 


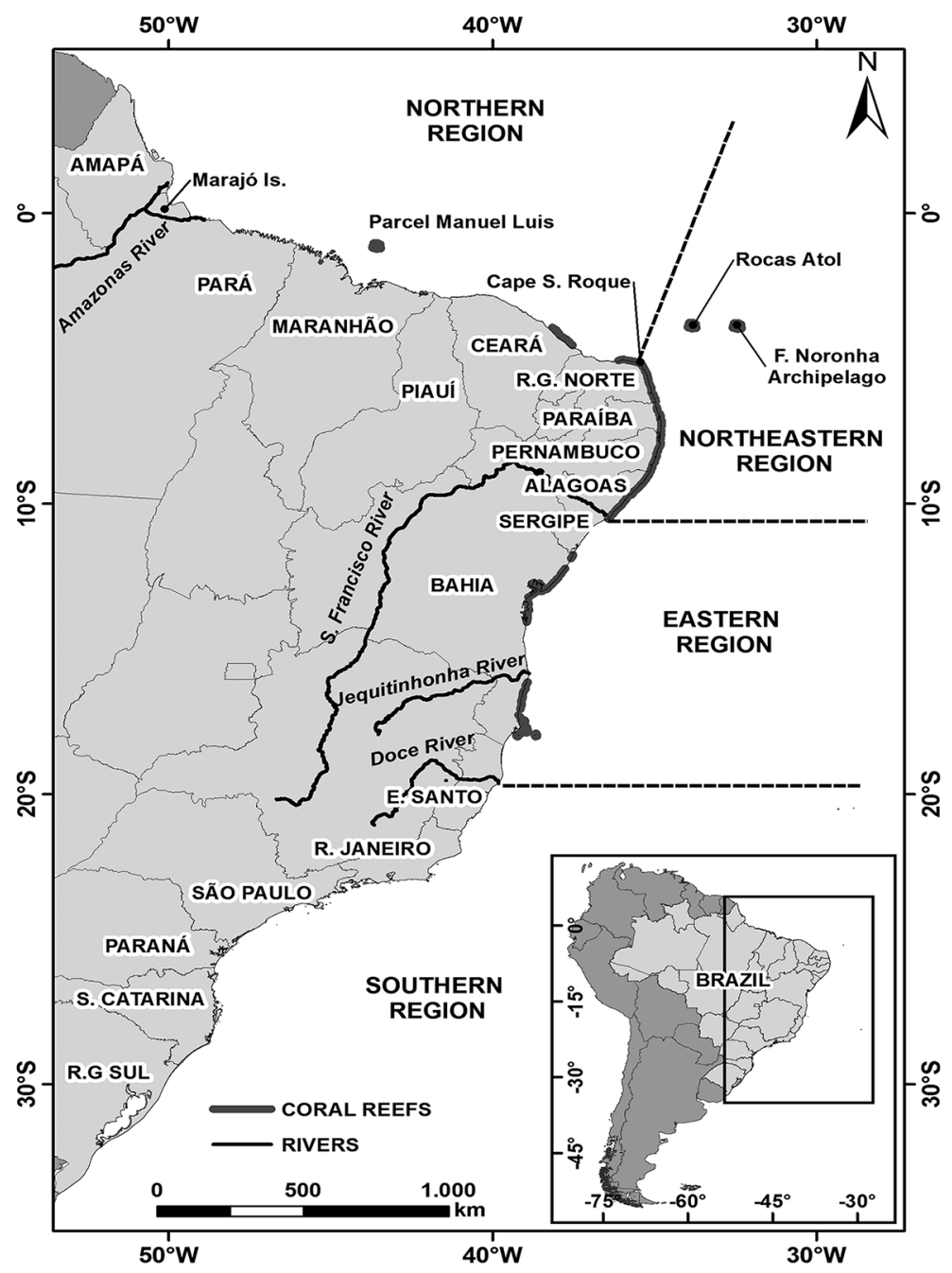

Figure 1. Location of the coral reef regions along the Brazilian coast.

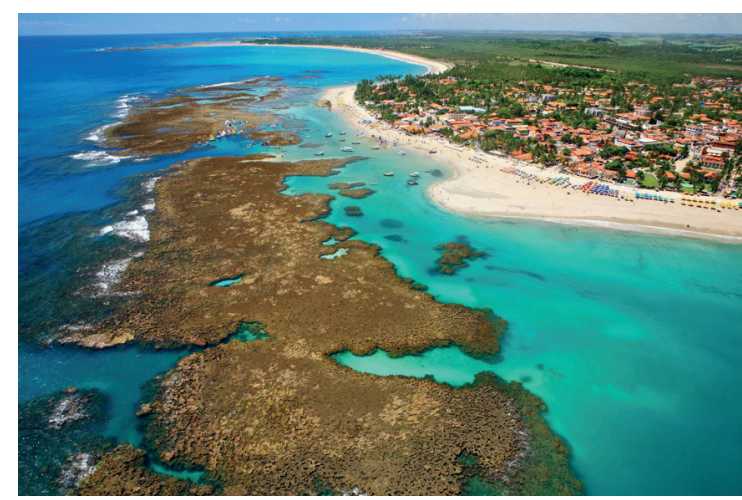

Figure 2. Aerial photograph of Porto de Galinhas coral reef on the coast of the State of Pernambuco, on the northeastern coast of Brazil.

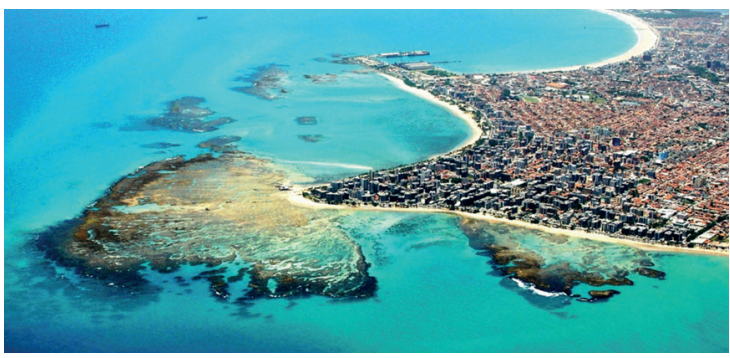

Figure 3. Aerial photograph of the Ponta Verde reef attached to the coast of the State of Alagoas on the northeastern coast of Brazil. 
The eastern region (from approximately $10^{\circ} \mathrm{S}$ to $18^{\circ} \mathrm{S}$ ) extends between the São Francisco and the Doce Rivers over 1,000 km along the coasts of the states of Sergipe and Bahia. This is the largest coral reef area along the entire Brazilian coast. The Sergipe shelf had been considered to lack coral reefs until recently when submerged reef structures that have not yet been mapped, were found (NEVES et al., 2005, 2006, 2010). Along the coast of the state of Bahia, the reefs can be subdivided into the following four major reef areas: the North Bahia coast, the Todos os Santos and Camamu Bays, the Cabrália/Porto Seguro area and the Abrolhos Bank reef complex. The North Bahia reefs are composed of shallow isolated bank reefs of various sizes that occur between the beaches of Abaí and Praia do Forte (KIKUCHI; LEÃO, 1998, KELMO; ATTRILL, 2001, LEÃO et al., 2003) (Figures 4 and 5). A cored reef revealed Holocene carbonate buildups with a thickness of approximately $10 \mathrm{~m}$ lying on a preCambrian rocky substrate (NOLASCO; LEÃO, 1986), and deeper reef structures occur towards the continental shelf break (KIKUCHI; LEÃO, 1998). In the area from Todos os Santos Bay to Camamu Bay, relatively continuous shallow fringing reefs border the islands' shores, and shallow bank reefs having a relatively round profile are to be observed in the interior of the bays (LEÃO et al., 2003; CRUZ et al., 2009, 2015; KIKUCHI et al., 2010). The Pinaunas reef that borders the shore of Itaparica Island in Todos os Santos Bay has a cored reef structure that is $8 \mathrm{~m}$ thick and of Holocene age that grew above the island substrate (ARAUJO et al., 1984) (Figure 6), and near Camamu Bay, a non-continuous line of shallow reefs borders the shore of the Tinhare and Boipeba Islands (Figure 7).

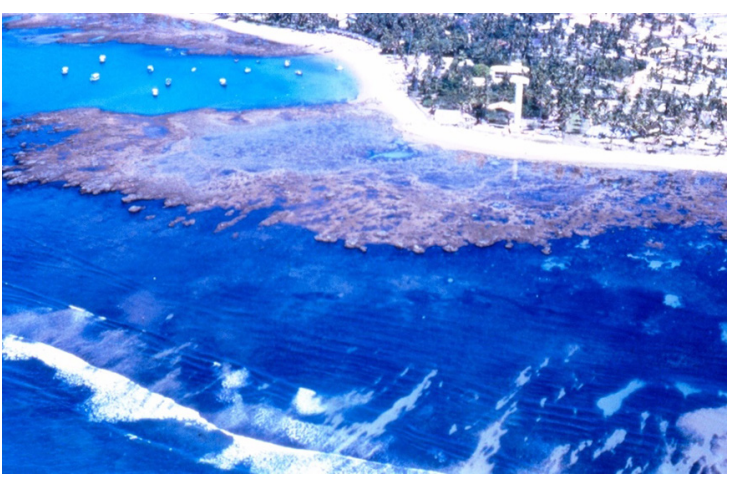

Figure 4. Aerial photograph of the Praia do Forte reef along the coast of the State of Bahia, in Eastern Brazil.

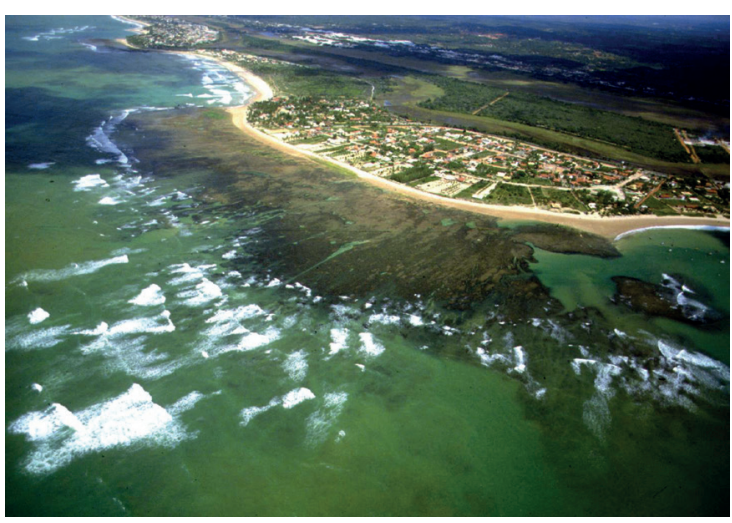

Figure 5. Aerial photograph of a reef attached to the coast of Itacimirim Beach on the coast of the State of Bahia, in Eastern Brazil.

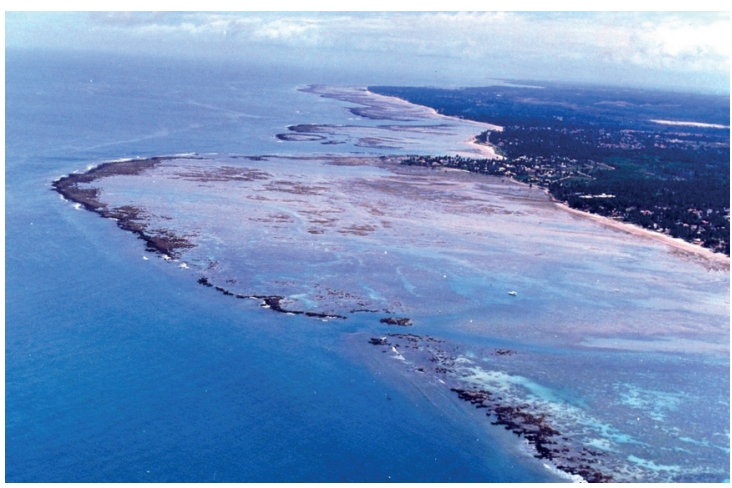

Figure 6. Aerial photograph of the Pinaunas fringing reef bordering the Itaparica Island shore at the entrance of Todos os Santos Bay, in Eastern Brazil.

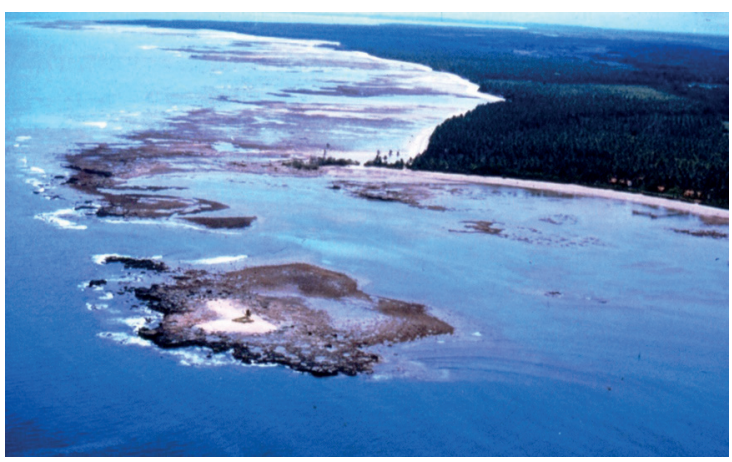

Figure 7. Aerial photograph of the shallow fringing reefs of Tinharé Island on the eastern coast of Brazil.

The area of Cabralia/Porto-Seguro is characterized by the presence of bank reefs of various shapes and dimensions in water no deeper than $20 \mathrm{~m}$, running mostly parallel to the coastline (COSTA JR et al., 2006) (Figure 8). The elongated reefs may have grown on 
submerged strings of beach rocks (LABOREL, 1970). A few kilometers off the coast of Porto-Seguro, the Recife de Fora lies the reef habitat most visited by tourists in this entire region. Southward, there are the Itacolomis reefs, which are the beginning of the occurrence of the Brazilian giant "chapeirões" and isolated bank reefs separated from one another by deep irregular channels (CASTRO et al., 2006a; CRUZ et al., 2008).

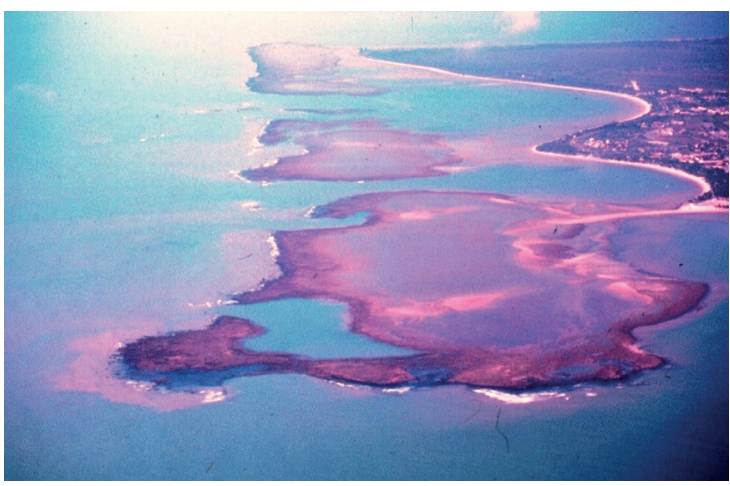

Figure 8. Aerial photograph of reefs of the Cabrália and Porto-Seguro region on the eastern coast of Brazil.

At approximately $17^{\circ} \mathrm{S}$, the continental shelf widens to form the Abrolhos Bank on which the richest and best known coral reefs of the eastern Brazilian region are located (HARTT, 1870; LABOREL, 1970, LEÃO, 1983; LEÃO et al. 1988, LEÃO et al., 1996, 1999; LEÃO; GINSBURG, 1997; VILLAÇA; PITOMBO, 1997; PITOMBO et al., 1988; LEÃO; KIKUCHI, 2001; LEÃO et al., 2003, 2006; PRATES, 2006; LEÃO; FOURNIER, 2007; LEÃO et al., 2008; FRANCINI-FILHO et al., 2008, 2010; among others). These reefs form the following two arcs: the coastal arc composed of bank reefs of various shapes and dimensions and the outer arc eastward of the islands of the Abrolhos Archipelago, which is formed by isolated "chapeirões" in water deeper than $20 \mathrm{~m}$. Incipient fringing reefs border the shores of the five islands that compound the archipelago (Figures 9 and 10). A cored reef on the coastal arc revealed a Holocene coral reef structure, over $12 \mathrm{~m}$ thick, lying on a reefal carbonate rock of probable Pleistocene age (LEÃO; LIMA, 1982; LEÃO; KIKUCHI, 1999). Southward in the Abrolhos Bank, in the northern part of the coast of Espírito Santo state, several coral species have been described (AMARAL et al., 2007).

Mesophotic reefs have been described across the mid and outer shelves of the Abrolhos Bank, at depths from 25 to $90 \mathrm{~m}$. These reefs are structures described as submerged pinnacles, coalescent reefs 2-3 m high with

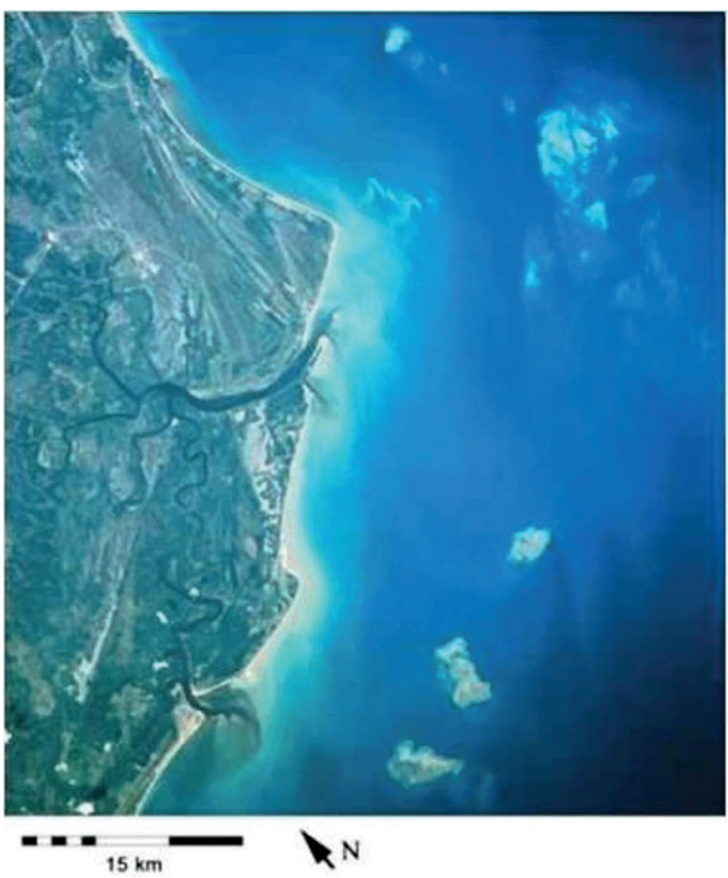

Figure 9. Satellite image illustrating the coral reefs of the coastal arc of Abrolhos.

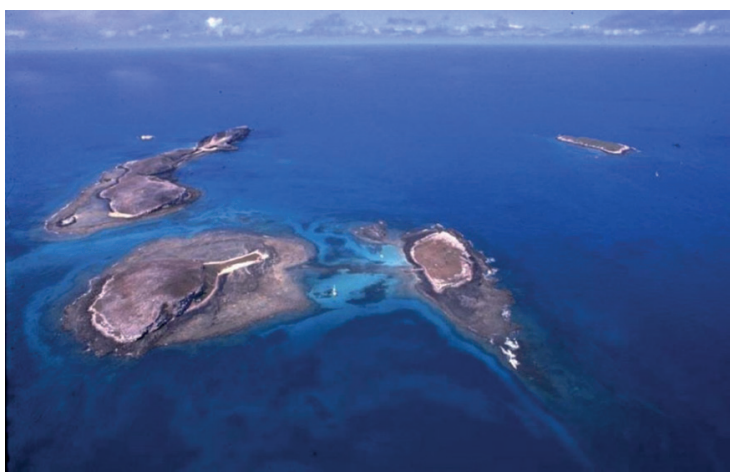

Figure 10. Aerial photograph of shallow fringing reefs surrounding the islands of the Abrolhos Archipelago in the southern portion of the state of Bahia, in Eastern Brazil.

sinkhole-like depressions known as "buracas". These reef structures are almost drowned reefs with low coral coverage. In the deep pinnacles, the coral Montastraea cavernosa dominates, and a sparse occurrence of Siderastrea spp., Agaricia spp., Porites spp., Madracis spp., Favia spp. and Scolymia spp., along with the black corals Cirripathes and Antipathes have been observed (MOURA et al., 2013; BASTOS et al., 2013).

In the southeastern and southern regions, from the mouth of the Doce River (19 $30^{\circ} \mathrm{S}$ ) to the coast of the state of São Paulo, no reef is known, although corals have been found. At Arraial do Cabo in the state of 
Rio de Janeiro, in the so-called "Laborel's coral oasis" (LABOREL, 1969), the coral species Siderastrea stellata and Mussismilia hispida have been found on several rocky shores (CASTRO et al., 1995; OIGMAN-PSZCZOL; CREED, 2004, 2006). The species Mussismilia hispida has also been observed on the coast of São Paulo state (MIGOTTO, 1995; MIGOTTO et al., 1999).

The reef ecosystems of the Oceanic Islands are composed of the coral communities of the Atol das Rocas, the islands of Fernando de Noronha and the São Pedro and São Paulo archipelago and certain coral species of the islands of Trindade and Martin Vaz. Rocas $\left(03^{\circ} 51^{\prime} \mathrm{S}-33^{\circ} 49^{\prime} \mathrm{W}\right)$ is an atoll that developed on the flat top of a seamount. Rocas has an elliptical shape with the longer axis (3.5 m long) oriented E-W and the minor axis (approximately $2.5 \mathrm{~m}$ long) oriented N-S. The reef ring is open on its western and northern sides. Despite its small dimensions, all of the characteristic features of a reef can be distinguished, such as the reef front, reef flat and a shallow lagoon. Rocas has been the subject of many studies over the last decades (MAŸAL; BEZERRA, 1995; KIKUCHI; LEÃO, 1997; ECHEVERRIA et al., 1997; MAIDA; FERREIRA, 1997; GHERARDI; BOSENCE, 1999, 2001; KIKUCHI, 2002; GHERARDI; BOSENCE, 2005; PEREIRA et al., 2010; SOARES et al., 2011a, 2011b) (Figure 11). The Fernando de Noronha Archipelago $\left(03^{\circ} 51^{\prime} \mathrm{S}-32^{\circ} 25^{\prime} \mathrm{W}\right)$ is composed of 21 islands and islets of volcanic origin, located approximately $350 \mathrm{~km}$ off the coast of Rio Grande do Norte state. These islands are part of the volcanic mountains of the Fernando de Noronha Chain (FERREIRA et al., 2013). True reefs have not been found on the islands, but an abundant coral fauna grows on their rocky shores (PIRES et al., 1992; MAIDA et al., 1995; MAIDA; FERREIRA, 1997; CASTRO; PIRES, 2001; PRATES, 2006; AMARAL et al., 2009; MILOSLAVICH et al., 2011). The São Pedro and São Paulo Archipelago (005' S - 29'22'W) consists of 15 rocky islets located approximately $1100 \mathrm{~km}$ off the coast of Rio Grande do Norte state, the largest being the Belmonte Islet, less than $100 \mathrm{~m}$ long and $50 \mathrm{~m}$ wide (VASKE JR et al., 2010). Few coral species have been reported on the rocky shores of these islets (LABOREL, 1970; AMARAL et al., 2000). The rocky islands of Trindade and Martin Vaz (20³0'S - 29²0'W) belong to the Vitória - Trindade Rock Chain, located approximately $1200 \mathrm{~km}$ off the coast of Espírito Santo state. No true reefs exist, but certain coral species have been reported on these islands (FLOETER et al., 2001).

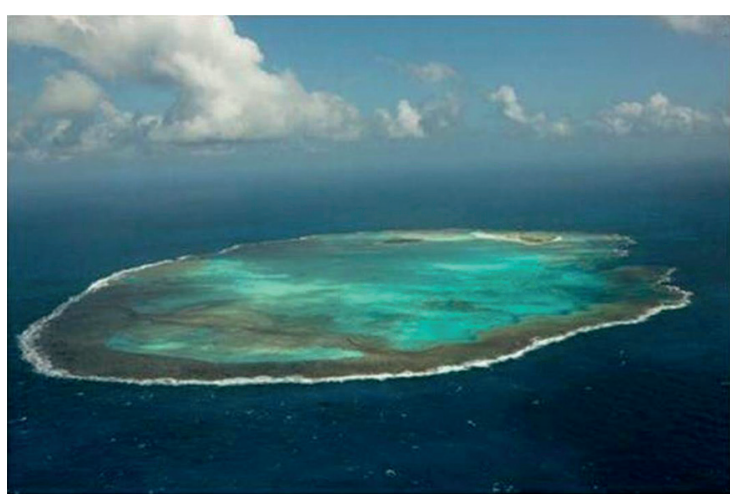

Figure 11. Satellite image of Atol das Rocas.

THE DIVERSITY OF THE REEF BUILDING CORAL FAUNA

The Scleractinian corals are the major framework reef builders and provide most of the structural complexity in the reef ecosystem. These corals grow into a rock-like colony that forms the basic structure of the coral reefs (GUEST et al., 2012) because they have a symbiotic relationship with the micro algae zooxanthelae, which supply the coral polyps with sufficient energy to build their protective calcium carbonate skeleton.

The Scleractinia coral fauna of Brazil has the following three distinctive characteristics: i) it is a low diversity coral fauna (23 corals and five hydrocorals) compared with that of the North Atlantic reefs; ii) the major reef builders are species endemic to Brazilian waters, and iii) it is predominantly composed of massive forms.

The first descriptions of the Brazilian corals were taken from those collected during Hartt's expeditions to Brazil (HARTT, 1869, 1870) and subsequently identified by VERRILL (1868, 1901, 1912). Later, LABOREL (1967, 1969) compared Verrill's taxonomy with contemporary forms and Tertiary fossils and corroborated Verrill's remarks that among the Brazilian reef frame builders, endemism is rather strong. Later in the $20^{\text {th }}$ century, BELEM et al. (1986) and CASTRO (1994) confirmed and expanded Laborel's list, and, more recently, additions of new coral and hydrocoral species have been made. NEVES et al. (2005, 2006, 2008,2010 ) have described two new occurrences of the genus Siderastrea in Brazil, Siderastrea radians and S. siderea, and a new species of Scolymia, S. cubensis (NEVES et al., 2006). AMARAL et al. $(2007,2008)$ have described the new species Millepora laboreli, from the reefs of the Manuel Luis State Park (Maranhão State). 
Two invasive coral species have also been added to the list of the Brazilian coral fauna, Tubastraea tagusensis and $T$. coccinea. These invasive coral species have been described in reefs from Todos os Santos Bay (MIRANDA et al., 2012; SAMPAIO et al., 2012), on rocky shores in the state of Rio de Janeiro (PAULA; CREED, 2005; CREED, 2006; CREED; PAULA, 2007; FERREIRA et al., 2013), and incrusting oil platforms in the states of Santa Catarina (MANTELATTO et al., 2011, RIUL et al., 2013) and Espírito Santo (COSTA et al., 2014). To date, 23 species of stony corals and five species of hydrocorals constitute the cnidarian fauna of Brazil (Figure 12).

\section{THE MAJOR ENVIRONMENTAL EFFECTS ON}

\section{THE REEFS}

\section{NATURAL DISTURBANCES}

Because the Brazilian reefs experience no hurricanes and overlie a passive continental shelf, the effects of the natural disturbances recorded in our reefs are related only to the sea level oscillations that have occurred over the last $5 \mathrm{ky}$ and their effects.
The sea level history during the late Holocene period shows that the Brazilian coast experienced relatively considerable sea level fluctuations (MARTIN et al., 1979, 1985). These sea level oscillations have exerted profound effects on the evolution of the coral reefs. The late Holocene regression that occurred over the last $5 \mathrm{ky}$ has been responsible for the degradation phase of the nearshore reefs. As previously described, the lowering of the sea level exposed the reef tops to marine erosion, dissolution and extensive bioerosion. Furthermore, the reef communities dwelling on these tops experienced stress, primarily resulting from strong solar radiation and high levels of sedimentation and water turbidity. Several $14 \mathrm{C}$ dates from the tops of the coastal bank reefs, ranging from 3.18 to $6.00 \mathrm{ky}$ BP (LEÃO et al., 1985, 1997; MARTIN et al., 1996; KIKUCHI; LEÃO, 1998; LEÃO et al., 2003; LEÃO; KIKUCHI, 2005), provide evidence that the reefs reached heights higher than the present sea level and that they were truncated by erosion due to falls in sea level. On these flattened reef tops, which are completely subaerially exposed during low tides, living corals occur only within the tidal pools.

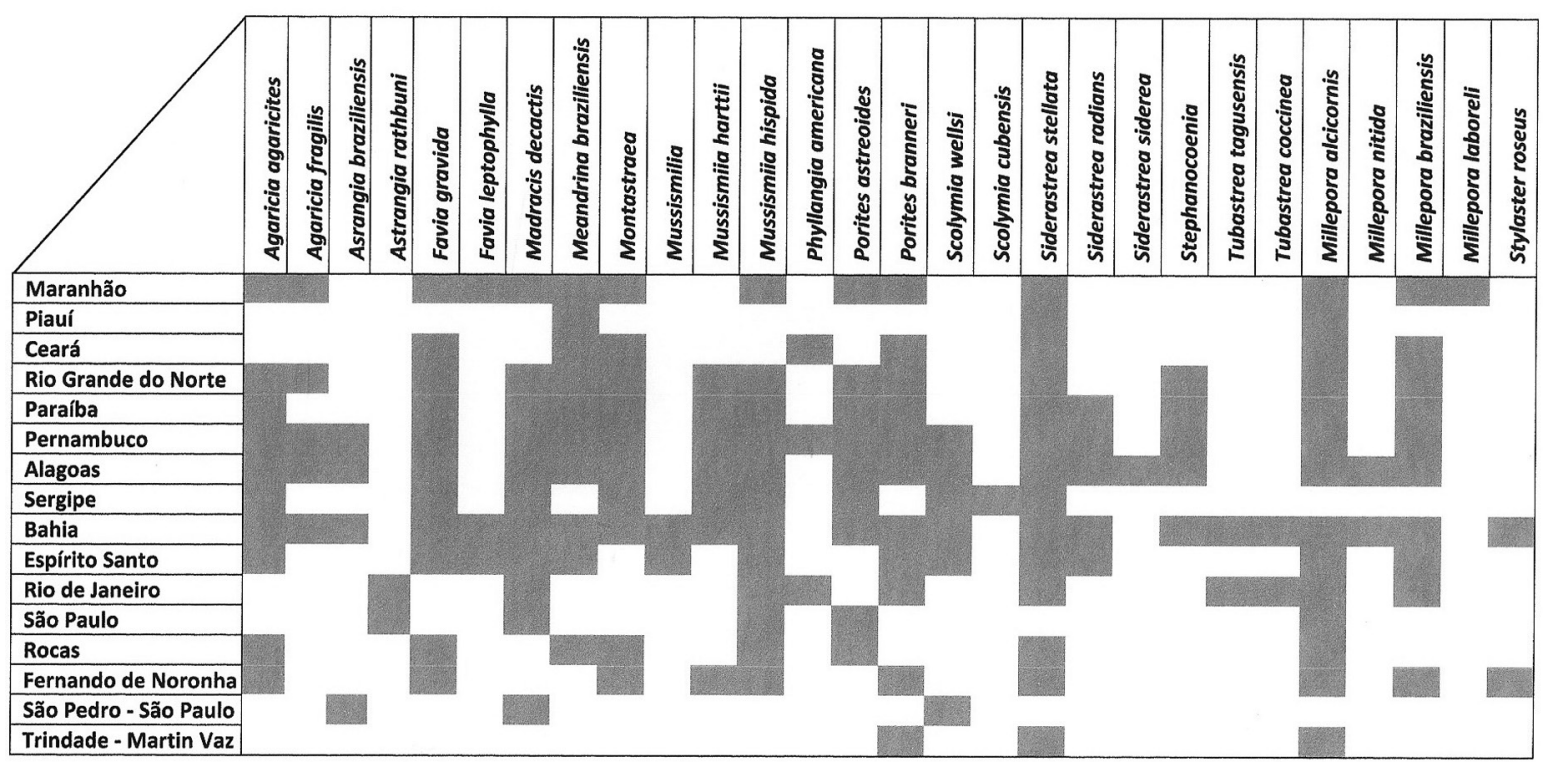

Figure 12. Distribution of coral and hydrocoral species along the coast of Brazil. Northern Region: states of Maranhão, Ceará, Piauí and north part of Rio Grande do Norte. Northeastern Region: east coast of Rio Grande do Norte, and the states of Paraíba, Pernambuco and Alagoas; Eastern Region: Sergipe, Bahia and Espírito Santo states; Southeastern and Southern Regions: Rio de Janeiro and São Paulo; Oceanic Islands: Rocas, Fernando de Noronha, São Pedro/São Paulo Archipelago and islands of Trindade and Martin Vaz. Data from: LABOREL (1969,1970); BELÉM et al. (1986); TESTA (1997); CASTRO (1994); CASTRO et al. (2006); MAŸAL; BEZERRA (1995); ECHEVERIA et al. (1997); MAIDA; FERREIRA (1997); AMARAL et al. (2006, 2007, 2008, 2009); PAULA; CREED (2005); OIGMAN-PSZCZOL; CREED (2004, 2006); CASTRO et al. (2006a); CREED (2006); NEVES et al. (2005, 2006, 2008, 2010); CREED; PAULA (2007); CREED et al. (2008); CORREIA; SOVIERZOSHI (2010); CORREIA (2011); MANTELATTO et al. (2011); MIRANDA et al. (2012); SAMPAIO et al. (2012). 
In these tidal pools, variations in the water temperature and salinity along with long exposures to strong solar radiation are stress factors for most of the coral species. Small colonies of the endemic species Siderastrea stellata and Favia gravida are the only corals that inhabit this reef environment.

Increased coastal sedimentation during the regression subjected the reefs to the influence of a highly siliciclastic sediment influx. Data from several areas along the northeastern and eastern coasts of Brazil show that the nearshore reefs are located in a sedimentary province dominated by terrigenous sediments, either relict or modern. In the northeastern region, for example, the sediments on the reefs of Rio do Fogo and Sioba, on the coast of the state of Rio Grande do Norte, have more than 55\% of relict siliciclastic constituents (TESTA, 1997). Along the entire coast of the state of Bahia (the eastern region), on the nearshore reefs, 40 to $80 \%$ of the perireefal sediments have terrestrial sources (NOLASCO; LEÃO, 1986), particularly in the Abrolhos area (LEÃO; GINSBURG, 1997; BARROS; PIRES, 2006, DUTRA et al., 2006a; SEGAL; CASTRO, 2011). All of these siliciclastic sediments are unconsolidated muddy sands derived from ancient deposits that cover most of the hinterland and outcrops along the coast, mostly of the Tertiary Barreiras Formation that can also occur submerged on the inner shelf and, to a minor degree, from river outputs that are carried out to the reefs during winter storms. These environmental conditions, such as strong solar radiation, low light levels and high sediment influx, must exceed the tolerance levels of most of the Brazilian coral species. Only the most resistant and the best adapted species withstand the stressful conditions of our coastal waters.

\section{HUMAN-INDUCED EFFECTS}

Many coral reefs in the world are seriously threatened by anthropogenic action, particularly those located in embayments and near shallow shelves lying off densely populated areas, due to deforestation, intensive agriculture, urbanization and the consequent increases in the nutrient and sediment loads along with many other types of pollution. Additional human-associated factors that degrade coral reefs are overharvesting of reef organisms, destructive fishing methods, and uncontrolled tourism (GRIGG; DOLLAR, 1990; ROBERTS, 1995; DULVY et al., 1995; JENNINGS; POLUNIN, 1996).

The most common anthropogenic agents that threaten the coastal reefs of Brazil have been described in several publications, and they are directly related to coastal runoff and urban development, marine tourism, trading of reef organisms, predatory fishing, the installation of industrial projects, and the exploitation of fossil fuels (MAŸAL, 1986; COUTINHO et al., 1993; LEÃO, 1994; LEÃO et al., 1994; AMADO FILHO et al., 1997; MAIDA; FERREIRA, 1997, LEÃO et al., 2003). Although coral diseases were registered, for the first time, in the reefs from Abrolhos Bank only in 2005, they already represent a threat to the reefs in the region (FRANCINI-FILHO et al. 2008).

\section{COASTAL RUNOFF}

Although Brazilian coastal reefs have been coexisting with a muddy siliciclastic influx for a long time, they clearly, recently, have appeared to be under greater stress, primarily due to the increased coastal runoff. This increase can be attributed to the increasing deforestation of the Atlantic coastal rainforest for agricultural and industrial purposes, initially for sugar cane and coconut plantations, then to allow timber exploitation, and over the last few decades, to cultivate eucalyptus for industrial use. This rapid deforestation has significantly increased the runoff and the untreated sewage discharges from expanding urban centers, leading to abnormally high nutrient and algal growth at the expense of the corals. In the northeastern region, for example, the sugar cane monoculture forms a belt that is approximately $60 \mathrm{~km}$ wide and nearly $100 \mathrm{~km}$ long and located a few kilometers inland in the area in which the nearshore reefs are more numerous (MAIDA; FERREIRA, 1997). Along the eastern region, the effects of the increasing sedimentation rates are negatively correlated with the biotic parameters of the reef biota (DUTRA et al., 2006a, b; SEGAL et al. 2008; SEGAL; CASTRO, 2011), and the increase in the deposition of terrigenous mud near the inshore reefs over the last decades may significantly affect the reefs on the short term, even though the Brazilian coral fauna has already been surviving in turbid waters for a long time (SILVA et al., 2013).

\section{URBAN DEVELOPMENT}

The unrestrained urban development in the coastal areas, primarily on the outskirts of the municipalities that already offer an infrastructure for tourism, with an extension of nearly $3,000 \mathrm{~km}$ along the Brazilian coast, is a potential threat to the reefs. The untreated urban garbage and organic sewage coming from those areas adjacent to the reefs is causing, in certain locations, an abnormal increase in the 
nutrients in the reef's biota, with dramatic consequences for the ecological balance of the environment. The measurements of the nutrient levels of the ground water of two villages along the coast of the state of Bahia, for example, show levels significantly higher than the normal conditions of the coastal waters (COSTA JR et al., 2000; 2006; COSTA JR, 2007). The influence of this enrichment in the nutrient levels caused by ground water contamination favors the activity of planktivorous macroborers (sponges and bivalves) in the nearshore reefs at levels that can be considered deleterious to the reefs due to the active bioerosion process which they promote (SANTA-IZABEL et al., 2000; REIS; LEÃO, 2003).

\section{MARINE TOURISM AND OVEREXPLOITATION OF REEF} ORGANISMS

Associated with the disorderly growth of the coastal towns and representing, in certain cases, the primary reason for their expansion, the marine tourism industry in Brazil has recently experienced extensive growth. The majority of the cities along the coast have been growing at the alarming rate of more than 1,000\% over recent decades. The anchoring and beaching of boats, the scattering of litter, the movements of divers that either lean against or bump into the corals, and walking on the reef tops can damage the reefs. These activities, if not properly controlled, may have serious effects on the reef ecosystem. In the Abrolhos area, for example, only the reefs inside the limits of the Abrolhos National Marine Park are subject to a certain amount of control (SPANO et al., 2008). The reefs of the nearshore zone that comprise three-fourths of the total area of the reefs are not under any type of control (LEÃO et al., 1994). In addition to these reefs being located closer to the urban centers, there is no restriction to their recreational or commercial use, and they are subject to the highest fishing pressure in the entire region (FRANCINI-FILHO; MOURA, 2008; FRANCINI-FILHO et al., 2013). Several examples of reef areas explored by marine tourism have been registered in the literature, and they are already threatened. Certain examples in the northeastern region are the coral reefs along the coast of Maceio city in which the macrobenthic reef populations are reacting to the human effects caused by intense tourism (CORREIA; SOVIERZOSKY, 2010). On the Coral Coast of the state of Pernambuco, the marine tourism in the area of the coastal reefs is causing serious problems for the conservation of the reefs (MAIDA; FERREIRA, 2003; STEINER et al., 2006). Also in the
State of Pernambuco, more recent studies of the reefs of Porto de Galinhas have observed a higher percentage of bare areas in which people are taken by boat to walk on the reef tops and practice snorkeling (BARRADAS et al., 2010, 2012). The demand for the reef animals as souvenirs and the aquarium trade has been intensifying in the reef areas throughout the length of the Brazilian coast. The corals have been being extracted for many years for the commerce of souvenirs in several areas of the reefs in the northeastern region (MAYAL, 1986). According to GASPARINE et al. (2005), Brazil is one of the five leading exporting countries of tropical aquarium fishes in the world, and the interest in marine ornamental organisms increased substantially from the mid to the late 1990s. In the Picãozinho reefs in the state of Paraiba, the trade in reef organisms, particularly of corals and fishes, is a common activity (ILLARI et al., 2007). In many coastal cities along the entire coast, particularly in the historical villages (i.e., in south Bahia), we can verify that for centuries, corals have been mined for building materials for the construction of old fortresses dating back to the $16^{\text {th }}$ century and, currently, for the construction of rustic beach resorts.

THE EFFECTS OF OCEAN WARMING ON THE CORAL REEFS

\section{Coral BLEACHING EVENTS}

Coral bleaching occurs when an environmental stress causes a disruption in the symbiotic relationship between the corals and their endosymbiotic algae zooxanthella (FITT, et al. 1993, MULLER-PARKER; D'ELIA, 1997). Because these microalgae living in the coral tissue provide a significant portion of the energy required by the coral to survive, when its photosynthetic pigments are expelled or lost during a prolonged or severe stress, partial or complete coral mortality may result (BROWN, 1997). In most registers of coral bleaching it is attributed to the abnormal increases in the temperature of the ocean waters (GLYNN, 1993, BROWN, 1997) which occur most frequently during El Niño events as, for example, during the events of 1982/83 (GLYNN, 1984), 1997/98 (WILKINSON, 2000), 2002/03 (BERKERMANS et al., 2004), 2005 (BRANDT, 2009; EAKIN et al., 2010) and, more recently, the strong and widespread event of 2010 when the coral reefs of several areas of the world were exposed to a higher magnitude of thermal stress (KRISHNAN et al., 2011, GUEST et al., 2012). 
Most of the registered coral bleaching episodes have demonstrated that the effects of the thermal stress are a threat to the biodiversity and abundance of the coral reefs (WILKINSON, 2004; CARPENTER et al., 2008), also causing a negative effect on the growth of the coral species (EVANGELISTA et al., 2007).

The first registers of coral bleaching in Brazil occurred in the southern hemisphere summer of 1993/1994. An extensive bleaching of the species Mussismilia hispida and Madracis decactis occurred on the coast of the state of São Paulo (the southern region) (MIGOTTO, 1995) and in the area of the Abrolhos reefs (the eastern region) (CASTRO; PIRES, 1999). Regarding the São Paulo event, the author has cited an anomalous rise in the sea surface temperature as the major cause for the bleaching and has reported that after six months, all of the bleached colonies had recovered. On the northeastern coast, during the summer of 1996, bleached corals were observed during the months in which the ocean temperature reached values between $29^{\circ} \mathrm{C}$ and $30^{\circ} \mathrm{C}$, but the corals recovered their normal colors when the water temperature returned to values between $26^{\circ} \mathrm{C}$ and $28^{\circ} \mathrm{C}$ (COSTA et al., 2001).

The strong El Niño event that began at the end of 1997 in the Pacific ocean caused a rise in the sea surface temperature in certain regions of the Brazilian coast as well. The sea temperature rise in Brazil started in midJanuary 1998 (the summer in the southern hemisphere), attained its climax in mid-March and early April, and faded away at the end of May (data obtained from the Monthly Climatology Charts produced by Dr. Allan Strong, NOAA/NESDIS). During this period, a new bleaching event occurred in several sectors of the Brazilian coast, which were coincident with the oceanic thermal anomalies (KIKUCHI et al., 2003; LEÃO et al., 2003; KELMO et al., 2003; FERREIRA et al., 2006).

Between 2000 and 2010, severe coral bleaching events occurred in 2003, 2005 and 2010, all of which coincided with the period of the rising water temperature during El Niño. In the northeastern region during the event of 2003, approximately 30\% of Siderastrea stellata colonies from the Cape Branco reefs in the state of Paraíba were affected (COSTA et al., 2001, AMORIM et al., 2011), and there are registers of bleached corals in the Rocas Atoll, the Fernando de Noronha Archipelago and from reefs along the coast of the state of Pernambuco (FERREIRA et al. 2006). For the eastern region, coral bleaching events were registered either in the summer of 2003 or that of 2005, but all of the corals recovered after the sea water temperature returned to its normal values (OLIVEIRA et al., 2007; LEÃO et al., 2008, 2009; KRUG et al., 2012, 2013). In 2010, the high sea surface temperatures that were recorded in several parts of the world as causing coral bleaching were also recorded in the Brazilian reef areas. In the Atol das Rocas and Fernando de Noronha Archipelago, the temperature anomaly reached $1.67^{\circ} \mathrm{C}$ above average at the reef sites (FERREIRA et al., 2013). Along the coast of the state of Ceará, the first bleaching event recorded affected the corals Siderastrea stellata and Favia gravida and the zoanthid Zoanthus sociatus in an intertidal beachrock reef during the period of high sea surface temperatures $\left(30^{\circ} \mathrm{C}\right.$ to $\left.32^{\circ} \mathrm{C}\right)$ for four to seven weeks (SOARES; RABELO, 2014). In the eastern region, severe coral bleaching affected the reef areas along the coast of the state of Bahia when thermal anomalies of up to $1^{\circ} \mathrm{C}$ were recorded (MIRANDA et al., 2013, KIKUCHI et al., 2013) (Figure 13).

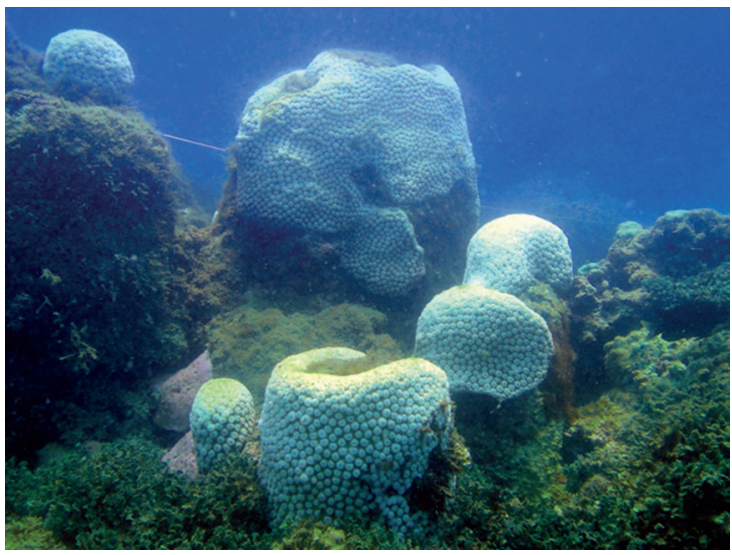

Figure 13. Photograph of bleached corals along the eastern coast of Brazil during the 2010 El Niño event. (Photo courtesy of R. Miranda).

Considering all the registers of coral bleaching in Brazil prior to 2005, the studies of KRUG et al. (2012) and the model developed by KRUG et al., (2013) show that the bleaching events in the eastern region, are strongly related to occurrences of sea surface temperature anomalies. Although, in most of cases, bleaching had affected several reef areas with great intensity, prior to the 2010 event, no episodes of coral mass mortality had been recorded (KIKUCHI et al., 2010; LEÃO et al., 2008, 2010; KRUG et al., 2012, MIRANDA et al., 2013; KIKUCHI et al., 2013; FERREIRA et al. 2013). 


\section{How to EVALUATE AND MITIGATE THE EFFECTS ON} THE BRAZILIAN CORAL REEFS

Although the Brazilian coral fauna has shown resistance to bleaching and mortality and may be functionally adapted to the stressful condition of the highly turbid coastal waters, a synergism of these processes with the current anthropogenic disturbances can aggravate the recovery capacity of this already disturbed coral community. Improvements in protective measures should be enforced in the existing Brazilian Conservation Units, identifying priorities for action, such as campaigns to change people's attitude towards reef conservation, to strengthen monitoring programs and the value of reef assessment and to demonstrate the need for and effectiveness of management practices to decision-makers.

\section{Protection and Management}

Scientific information about the coral reefs in Brazil has existed for over a century; however, knowledge as to the actual condition of the reefs in terms of their protection is scarce, and for certain areas, was virtually unknown until recently, when an initiative of the Directorate of Protected Areas of the Brazilian Ministry of Environment (DAP-MMA) developed a project for the conservation of the coral reefs, expending effort in mapping the shallow reefs found in the existing Conservation Units. This "Atlas of Coral Reef Protected Areas of Brazil" provides a considerable increase in the useful information available, especially regarding monitoring of the reefs and the preparation or updating of management plans for the Conservation Units (PRATES, 2006).

The Conservation Units are distributed along the entire coast of Brazil and include nearly all of the country's oceanic islands, with different management categories at the following three levels of government: federal, state and municipality (PRATES; PEREIRA, 2000). Two of the nine existing Conservation Units, at the time when the Atlas was prepared, were on oceanic islands, the Biological Reserve of Atol das Rocas and the National Marine Park of Fernando de Noronha (both of these were designated as Natural World Heritage Sites in 2001); three were on the limits of reef distribution, in the State Marine Park of Parcel de Manuel Luiz, in the state of Maranhão (designated a Ramsar Site in 2000), the National Marine Park of Abrolhos and the State Environmental Protection Area of Ponta da Baleia, both in the state of Bahia. The remaining four were on more coastal areas, as follows: the
State Environmental Protection Area of Recifes de Corais in the state of Rio Grande do Norte, the Environmental Protection Area of Costa dos Corais in the states of Pernambuco and Alagoas, the Municipal Marine Park of Recife de Fora, in the state of Bahia, and the Marine Extractive Reserve of Corumbau, also in the state of Bahia (PRATES, 2006). In a second initiative of the DPA-MMA, the "Coral Reef Conservation Campaign", seven other Conservation Units were added to the list, as follows: the Environmental Protection Area of Fernando de Noronha, Rocas and São Pedro, São Paulo, the State Marine Park of Areia Vermelha, in the state of Paraiba, and the Environmental Protection Area of the Baía de Todos os Santos, the Environmental Protection Area of the Recife das Pinaunas, the Environmental Protection Area of Tinharé-Boipeba, the Marine Municipal Park of Coroa Alta and the Marine Municipal Park of the Recife da Areia, all of which are in the state of Bahia. The primary purpose of the Coral Reef Conservation Campaign is to increase the awareness of the various users of the coral reef areas as regards the importance and fragility of these environments, disseminating rules for responsible conduct to preserve these areas in their original state, in view of the fact that coral reefs are one of the most endangered ecosystems in the world (PRATES et al., 2002).

Concurrent with the official initiatives, every citizen (including divers, fishermen, tourists, businessmen, government officials, teachers, students, scientists, among others) should take preventive measures to protect the reefs. These measures may include personal ones, involving the choice of a proper place to anchor, suitable handling of garbage, avoiding the collection of living corals or any other reef organisms, reducing marine pollution, habitat degradation and destructive fishing practices, and supporting or participating in the actions of groups, organizations or companies concerned with the protection of coral reefs. To ensure that the coral reefs will continue to exist for future generations, we must reduce the greenhouse gases that are warming and acidifying the ocean. These attitudes will establish the critical levels of the effects on the reef communities, will permit a better understanding of the Brazilian coral reefs, and will provide support for their effective management.

\section{ReEF Monitoring AND Assessment}

The effective management responses depend on the availability of adequate information and its evaluation. 
This process will become possible through monitoring programs that cover all the aspects related to the essential components of the ecosystem, providing real-time information. Long-term monitoring programs, at protected and unprotected sites, will make possible the construction of a consistent view of reef decline associated with information on the environmental conditions related to the major degradation events. To monitor the coral reefs, the Global Coral Reef Monitoring Network (GCRMN) has adopted several monitoring protocols, which have been used in different regions around the globe to evaluate the health and dynamics of the reef environment. Many of these protocols are comparable because the evaluation methods are similar.

In Brazil, several methods have been used to evaluate the coral reefs. Two of the methods that were adopted by certain participants of the ReBentos are included in the GCRMN, as follows: the Reef Check (FERREIRA et al. 2006) and the Atlantic and Gulf Rapid Reef Assessment (AGRRA Version 5.4; LANG et al., 2010). These two programs already have data from reef assessment spanning more than 10 years. To compare the condition of the reefs along the entire tropical coast, components of the Coral Reef Work Group of the INCT AmbTropic (National Institute of Science and Technology for the Tropical Marine Environments) and of the ReBentos have developed a Field Protocol, which includes the common points from the various methods that have hitherto been used. The objective of the Protocol is to assess the vulnerability, resilience and resistance of the coral reef ecosystems in Brazil that are facing the effects of anthropogenic and climate change and to generate information on the health and demographic connectivity between the reefs, which is important information for the adoption of effective management and conservation tools. A comparison of the spatial-temporal variations observed in the coral reef ecosystems of the continental shelf and the oceanic islands is intended to determine and understand the capacity of these ecosystems to withstand and recover from disturbances of different degrees of intensity in view of the spatial heterogeneity characterized by morphological, structural and compositional differences of the reefs and the «health» of the protected systems and those most exposed to threats. As indicators for the assessment of the condition of the reefs, the protocol will use the corals and reef fishes. For the corals, the protocol will use the following: richness and diversity, the relative reef area covered by living corals, percentage of bleaching, colonies affected by diseases, recent and old mortality and the density of the coral recruits. For the fishes, the protocol will use the following: density, richness and diversity per family and per group (herbivores, carnivores and omnivores) and measurements of their size. The relative coverage of the functional groups of algae (macro, coralline, and turf), sponges, zoanthids, sea urchins and other organisms considered important for the reefs investigated will also be considered (LEÃO et al. 2015). We hope that in the near future we shall be in possession of an accurate assessment of the condition of Brazilian coral reefs.

\section{ACKNOWLEDGEMENTS}

The authors are grateful to all who took some part in the field work teams, especially our students. The data presented in this article originated from several projects with financial support from various sources: CNPq, FAPESB, FINEP, CAPES. We would also thank the Abrolhos National Marine Park administration for their logistic support. ZMANL, RKPK, BPF, EGN, MDMO and MM integrate the Reef Ecosystems Work Group of the INCT Ambientes Marinhos Tropicais (Inct AmbTropic - CNPq \#565.054/2010-4).

\section{REFERENCES}

AMADO FILHO, G. M.; ANDRADE, L. R.; REIS, R. P.; BASTOS, W.; PFEIFFER, W. C. Heavy metal concentrations in seaweed species from the Abrolhos reef region, Brazil. Proc. $8^{\text {th }}$ Intern. Coral. Reef. Symp., v. 2, p. 1843-1846, 1997.

AMARAL, F. M. D.; HUDSON, M. M.; SILVEIRA, F. L.; MIGOTTO, A. E.; PINTO, S. M.; LONGO, L. L. Cnidarians from St. Peter and St. Paul Archipelago, Northeast Brazil. Proc. $9^{\text {th }}$ Intern. Coral. Reef. Symp., v. 1, p. 567-572, 2000.

AMARAL, F. M. D.; SILVEIRA, S. R. M.; VASCONCELOS, S. L.; RAMOS, C. A. C. Biodiversidade de cnidários bentônicos. In: VASKE JÚNIOR, T.; LESSA, R. P.; NÓBREGA, M.; AMARAL, F. M. D.; SILVEIRA, S. R. M. Arquipélago de São Pedro e São Paulo: histórico e recursos naturais. Olinda: Livro Rápido, 2006. p. 42-55.

AMARAL, F. M.; HUDSON, M. M.; STEINER, A. Q.; RAMOS, C. A. C. Corals and calcified hydroids of Manuel Luiz Marine Park (State of Maranhão, Northeast Brazil). Biota Neotropica, v. 7, n. 3, p. 73-81, 2007.

AMARAL, F. M. D.; STEINER, A. Q.; BROADHURST, M. K.; CAIRNS, S. D. An overview of the shallow water calcified hydroids from Brazil (Hydrozoa: Cnidaria), including the description of a new species. Zootaxa, v. 1930, p. 56-68, 2008 . 
AMARAL, F. M. D.; RAMOS, C. A. C.; LEÃO, Z. M. A. N.; KIKUCHI, R. K. P.; LIMA, K. K. N.; LONGO, L. L.; LIRA, S. M. A.; VASCONCELOS, S. L. Checklist and morphometry of benthic cnidarians from the Fernando de Noronha Archipelago, Brazil. Cah. Biol. Mar., v. 50, p. 277-290, 2009.

AMORIM, T. P. L; COSTA, C. F.; SASSI, R. Branqueamento e doenças em cnidários dos recifes costeiros de Picãozinho, Nordeste do Brasil. Tropical Oceanogr., v. 40, n. 1, p. 185201, 2011

ARAUJO, T. M. F.; LEÃO, Z. M. A. N.; LIMA, O. A. L. Evolução do recife de coral da ilha de Itaparica determinada a partir de dados geológicos e geofísicos. In: Congresso Brasileiro de Geologia. Rio de Janeiro: Anais, 1984. p. 159-169.

BARRADAS, J. I.; AMARAL, F. M. D.; HERNANDEZ, M. I. M.; MONTES, M. J. F.; STEINER, A. Q. Spatial distribution of benthic macroorganisms on reef flats at Porto de Galinhas Beach (northeastern Brazil), with special focus on corals and calcified hydroids. Biotemas, v. 3, n. 2, p. 61-67, 2010.

BARRADAS, J. I.; AMARAL, F. M. D.; HERNÁNDEZ, M. I. M.; FLORES-MONTES M. J; STEINER, A. Q. Tourism impact on reef flats in Porto de Galinhas Beach, Pernambuco, Brazil. Arq. Cien. Mar., v. 45, p. 81-88, 2012.

BARROS, M. M. L.; PIRES, D. O. Colony size frequency distribution among different populations of the Scleractinian coral Siderastrea stellata in Southwestern Atlantic: implications for life history patterns. Braz. J. Oceang., v. 54, n. 2, p. 213-223, 2006.

BASTOS, A. C.; MOURA, R. L.; AMADO-FILHO, G. M.; FRANCINI-FILHO, R. B.; FREITAS, M. O.; MINTEVERA, C. V.; TEIXEIRA, J. B.; GÜTH, A. Z.; SUMIDA, P. Y. G.; THOMPSON, F. L. Buracas: Novel and unusual sinkholelike features in the Abrolhos Bank. Cont. Shelf Res., v. 70, n. 1, p. 118-125, 2013.

BELÉM, M. J. C.; ROHLFS, C.; PIRES; D. O., CASTRO, C. B. S.O.S. Corais. Rev. Ciência Hoje, v. 5, p. 34-42, 1986.

BERKERMANS, R.; DE'ATH, G.; KININMONTH, S.; SKIRVING, W. J. A comparison of 1998 and 2002 coral bleaching events on the Great Barrier Reef: spatial correlation, patterns and predictions. Coral Reefs, v. 23, n. 1, p. 74-83, 2004.

BIRKELAND, C. Life and Death of Coral Reefs. New York: Chapman \& Hall, 1997.

BRANDT, M. E. The effects of species and colony size on the bleaching response of reef building corals in the Florida Keys during the 2005 mass bleaching event. Coral Reefs, v. 28, n. 4, p. 911-924, 2009.

BROWN, B. E. Coral bleaching: causes and consequences. Coral Reefs, v. 16, n. 1, p. S129-S138, 1997.

BURT, J.; AL-HARTHI, S.; AL-CIBAHI, A. Longterm impacts of coral bleaching events on the world's warmest reefs. Mar. Environ. Res., v. 72, n. 4, p. 225-229, 2011.

CARPENTER, K. E.; ABRAR, M.; AEBY, G.; ARONSON, R. B.; BANKS, S.; BRUCKNER, A.; CHIRIBOGA, A.; CORTÉS, J.; DELBEEK, J. C.; DEVANTIER, L.; EDGAR, G. J.; EDWARDS, A. J.; FENNER, D.; GUZMÁN, H. M.; HOEKSEMA, B. W.; HODGSON, G.; JOHAN, O.; LICUANAN, W. Y.; LIVINGSTONE, S. R.; LOVELL, E. R.; MOORE, J. A.; OBURA, D. O.; OCHAVILLO, D.; POLIDORO, B. A.; PRECHT, W. F.; QUIBILAN, M. C.; REBOTON, C.; RICHARDS, Z. T.; ROGERS, A. D.; SANCIANGCO, J.; SHEPPARD, A.; SHEPPARD, C.;
SMITH, J.; STUART, S.; TURAK, E.; VERON, J. E.; WALLACE, C.; WEIL, E.; WOOD, E. One-third of reefbuilding corals face elevated extinction risk from climate change and local impacts. Science, v. 321, p. 560-563, 2008.

CARTÉ, B. K. Biomedical potential of marine natural products. BioScience, v. 46, p. 271-286, 1996

CASTRO, C. B. Corals of Southern Bahia: In: HETZEL, B.; CASTRO, C. B. (eds.). Corals of Southern Bahia. Rio de Janeiro: Nova Fronteira, 1994. p. 161-176.

CASTRO, C. B.; ECHEVERRÍA, C. A.; PIRES, D. O.; MASCARENHAS, B. J. A.; FREITAS, S. G. Distribuição de Cnidaria e Echinodermata no infra litoral dos costões rochosos de Arraial do Cabo, Rio de Janeiro, Brasil. Rev. Bras. Biol., v. 55, n. 3, p. 471-480, 1995

CASTRO, C. B.; PIRES, D. O. A bleaching event on a Brazilian coral reef. Rev. Bras. Oceanog., v. 47, n. 1, p. 87-90, 1999.

CASTRO, C. B.; PIRES, D. O. Brazilian coral reefs: what we already know and what is still missing. Bull. Mar. Sci., v. 69, n. 2, p. 357-371, 2001.

CASTRO C. B.; AMORIM L. C.; CALDERON E. N.; SEGAL B. Cobertura e recrutamento de corais recifais (Cnidaria: Scleractinia e Milleporidae) nos recifes de Itacolomis, Brasil. Arq. Museu Nacional, v. 64, n.1, p. 29-40, 2006 a.

CASTRO, C. B.; SEGAL, B.; PIRES, D. O.; MEDEIROS, M. S. Distribution and diversity of coral communities in the Abrolhos Reef Complex, Brazil. In: ALLEN, G.; DUTRA, G. F.; WERNER, T. B.; MOURA, R. L. (Eds.). A Biological Assessment of Abrolhos Bank, Bahia, Brazil. Washington: RAP Bull. Biol. Assess, 2006b. p. 19-39.

CESAR, H. S. F.; VAN BEUKERING, J. H. Economic valuation of the coral reefs of Hawaii, Pacific Sci., v. 58, n. 2, p. 231242, 2004.

CONSTANZA, R.; d'ARGE, R.; GROOT, R.; FARBER, S.; GRASSO, M.; HANNON, B.; LIMBURG, K.; NAEEM, S.; O'NEIL, R.; PARUELO, J.; RASKIN, R.; SUTTON, R. The value of the world's ecosystem services and natural capital. Nature, v. 387, p. 253-260, 1997.

CORREIA, M. D.; SOVIERZOSHI, H. H. Macrobenthic diversity reaction to human impacts on Maceió coral reefs, Alagoas, Brazil. Proc. 11th Intern. Coral Reef. Symp., p. 1083-1087, 2010.

CORREIA, M. D. Scleractinian corals (Cnidaria: Anthozoa) from reef ecosystems on the Alagoas coast, Brazil. J. Mar. Biol. Assoc. U. K., v. 91, p. 659-668, 2011.

COSTA, C. F.; SASSI, R.; AMARAL, F. M. D. Branqueamento em Siderastrea stellata (CNIDARIA, SCLERACTINIA) da Praia de Gaibu, Pernambuco, Brasil, Rev. Nordestina Biol., v. 15 , n. 1, p. 15-22, 2001.

COSTA, C. F.; SASSI, R.; AMARAL, F. M. D. Annual cycle of symbiotic dinoflagellates from three species of scleractinian corals from coastal reefs of northeastern Brazil. Coral Reefs, v. 24, p. 191-193, 2005.

COSTA JÚNIOR, O. S.; LEÃO, Z. M. A. N.; NIMMO, M.; ATRILL, M. Nutrification impacts on coral reefs from Northern Bahia, Brazil. Hydrobiology, v. 440, n. 1, p. $307-$ 316,2000 .

COSTA JÚNIOR, O. S.; ATTRILL, M.; NIMMO, M. Seasonal and spatial controls on the delivery of excess nutrients to nearshore and offshore coral reefs of Brazil. J. Mar. Sys., v. 60, p. 63-74, 2006. 
COSTA JÚNIOR, O. S. Anthropogenic nutrient pollution of coral reefs in Southern Bahia, Brazil. Braz. J. Oceang., v. 55, p. 265-279, 2007.

COSTA, T. J. F.; PINHEIRO, H. T.; TEIXEIRA, J. B.; MAZZEI, E. F.; BUENO, L.; HORA, M. S. C.; JOYEUX, J. C.; CARVALHO-FILHO, A.; AMADO-FILHO, G.; SAMPAIO, C. L. S.; ROCHA, L. A. Expansion of an invasive coral species over Abrolhos Bank, Southwestern Atlantic. Mar. Poll. Bull., v. 85, n. 1, p. 252-253, 2014.

COURA, M. F. Contribuição ao Plano de Manejo do Parque Estadual Marinho do Parcel de Manuel Luiz, Ma. Brasil. 1994. 55 f. (Monografia). Departamento de Geociências, Universidade Federal do Maranhão, São Luís; 1994.

COUTINHO, R.; VILlAÇA, R. C.; MAGALHÃES, C. A.; GUIMARÃES, M. A.; APOLINARIO, M.; MURICY, G. Influência antrópica nos ecossistemas coralinos da região de Abrolhos, Bahia, Brasil. Acta Biol. Leopoldensia, v. 15, p. 133-144, 1993.

CREED, J. C. Two invasive alien azooxanthellate corals, Tubastraea coccinea and Tubastraea tagusensis, dominate the native zooxanthellate Mussismilia hispida in Brazil. Coral Reefs, v. 25, p. 350, 2006.

CREED, J. C.; PAULA, A. F. Substratum preference during recruitment of two invasive alien corals onto shallow subtidal tropical rocky shores. Mar. Ecol. Prog. Ser., v. 330, p. 101$111,2007$.

CREED, J. C.; OLIVEIRA, A. E. S.; PAULA, A. F. Cnidaria, Sclerctinia, Tubastraea coccinea Lesson, 1829 and Tubastraea tagusensis Wells 1982: distribution extension. Check List, v. 4, p. 297-300, 2008.

CRUZ, I. C. S.; KIKUCHI, R. K. P.; LEÃO, Z. M. A. N. Use of Video Transect Method for Characterizing the Itacolomis Reefs, Eastern Brazil. Braz. J. Oceang., v. 56, p. 271-280, 2008.

CRUZ, I. C. S.; KIKUCHI, R. K. P.; LEÃO, Z. M. A. N. Caracterização dos recifes de corais da área de preservação ambiental da Baía de Todos os Santos para fins de manejo, Bahia, Brasil. Rev. Gestão Costeira Integrada, v. 9, n. 3, p. 3-23, 2009.

CRUZ, I. C. S.; KIKUCHI, R. K. P.; LEÃO, Z. M. A. N.; DONE, T. J. Reef quality criteria for marine reserve selection: an example from eastern Brazil. Aquatic Conservation: Mar. Freshw. Ecosys., v. 25, n. 2, p. 223-234, 2015.

DAVIDSON, O. G. The enchanted braid. Coming to the terms with nature on the Coral Reef. New York: John Wiley \& Sons Inc, 1998. 269 p.

DE'ATH, G.; FABRICIUS, K, E.; SWEATMAN, H.; PUOTINEN, M. The 27 year decline of coral cover on the Great Barrier Reef and its causes. Proc. Nat. Acad. Sci. U S A., v. 109, n. 44, p. 17995-17999, 2012.

DOMINGUEZ, J. M. L.; BITTENCOURT, A. C. S. P.; LEÃO, Z. M. A. N.; AZEVEDO, A. E. G. Geologia do Quaternário Costeiro do Estado de Pernambuco. Rev. Bras. Geoc., v. 20, p. 208-215, 1990.

DONNER, S. D.; SKIRVING, W. J.; LITTLE, C. M.; OPPENHEIMER, M.; HOEGHGULBERG, O. Global assessment of coral bleaching and required rates of adaptation under climate change. Glob. Change Biol., v. 11, n. 12, p. 2251-2265, 2005.
DUTRA, L. X. C.; KIKUCHI, R. K. P.; LEÃO, Z. M. A. N. Effects of Sediment accumulation on reef corals from Abrolhos, Bahia, Brazil. J. Coast. Res., v. 39, p. 633-638, 2006 a.

DUTRA, L. X. C.; KIKUCHI, R. K. P.; LEÃO, Z. M. A. N. Todos os Santos Bay coral reefs, Eastern Brazil, revisited after 40 years. In: International Coral Reef Symposium, 10, 2004. Japan: Proceedings, 2006b. p. 1090-1095.

DULVY, N. K.; STANWELL-SMITH, D.; DARWALL, W. R. T.; HORRILL, C. J. Coral mining at Mafia Island, Tanzania: a management dilemma. Ambio, v. 24, n. 6, p. 358-365, 1995.

EAKIN, C. M.; MORGAN, J. A.; HERON, S. F.; SMITH, T. B.; LIU, G.; ALVAREZ-FILIP, L.; BACA, B.; BARTELS, E.; BASTIDAS, C.; BOUCHON, C.; BRANDT, M.; BRUCKNER, A. W.; BUNKLEY-WILLIAMS, L.; CAMERON, A.; CAUSEY, B. D.; CHIAPPONE, M.; CHRISTENSEN, T. R.; CRABBE, M. J.; DAY, O; DE LA GUARDIA, E.; DÍAZ-PULIDO, G.; DIRESTA, D.; GIL-AGUDELO, D. L.; GILLIAM, D. S.; GINSBURG, R. N.; GORE, S.; GUZMÁN, H. M.; HENDEE, J. C.; HERNÁNDEZ-DELGADO, E. A.; HUSAIN, E.; JEFFREY, C. F.; JONES, R. J.; JORDÁN-DAHLGREN, E.; KAUFMAN, L. S.; KLINE, D. I.; KRAMER, P. A.; LANG, J. C; LIRMAN, D; MALLELA, J.; MANFRINO, C.; MARÉCHAL, J. P.; MARKS, K.; MIHALY, J.; MILLER, W. J.; MUELlER, E. M.; MULLER, E. M.; OROZCO TORO, C. A.; OXENFORD, H. A.; PONCE-TAYLOR, D.; QUINN, N.; RITCHIE, K. B.; RODRÍGUEZ, S.; RAMÍREZ, A. R.; ROMANO, S.; SAMHOURI, J. F.; SÁNCHEZ, J. A.; SCHMAHL, G. P.; SHANK, B. V.; SKIRVING, W. J.; STEINER, S. C.; VILLAMIZAR, E.; WALSH, S. M.; WALTER, C.; WEIL, E.; WILLIAMS, E. H.; ROBERSON, K. W.; YUSUF, Y. Caribbean corals in crisis: record thermal stress, bleaching and mortality in 2005. PLoS ONE, v. 5, n. 11, p. e13969, 2010.

ECHEVERRÍA, C. A.; PIRES, D. O.; MEDEIROS, M. S.; CASTRO, C. B. Cnidarians of the Atol das Rocas, Brazil. Proc. 8t $\mathrm{t}^{\mathrm{h}}$ Intern. Coral Reef. Symp., v. 1, p. 443-446, 1997.

EVANGELISTA, H.; GODIVA, D.; SIFEDDINE, A.; LEÃO, Z. M. A. N.; RIGOZO, N. R.; SEGAL, B.; AMBRIZZI, T.; KAMPEL, M.; KIKUCHI, R. K. P.; LE CORNEC, F. Evidences linking ENSO and coral growth in the Southwestern-South Atlantic. Clim. Dyn., v. 29, n. 7, p. 869880, 2007.

FERREIRA, B. P.; MAIDA, M.; CASTRO, C. B.; PIRES, D. O.; D'AMICO, T. M.; PRATES, A. P. L.; MARX, D. The status of coral reefs of Brazil. Proc. $10^{\text {th }}$ Intern. Coral Reef. Symp., v. 1, p. $1011-1015,2006$.

FERREIRA, B. P.; COSTA, M. B. S. F.; COXEY, M. S.; GASPAR, A. L. B.; VELEDA, D.; ARAUJO, M. The effects of sea surface temperatures anomalies on oceanic coral reef systems in the southwestern tropical Atlantic. Coral Reefs, v. 32, n. 2, p. 441-454, 2013.

FITT, W. K.; SPERO, H. J.; HALAS, J.; WHITE, M. W.; PORTER, J. W. Recovery of the coral Montastraea annularis in the Florida Keys after the 1987 Caribbean "Bleaching Event”. Coral Reefs, v. 12, n. 2, p. 57-64, 1993.

FLOETER, S. R.; GUIMARÃES, R. Z. P.; ROCHA, L. A.; FERREIRA, C. E. L.; RANGEL, C. A.; GASPARINI, J. L. Geographic variation in reef fish assemblages along the Brazilian coast. Glob. Ecol. Biogeog., v. 10, p. 423-433, 2001. 
FRANCINI-FILHO, R.; MOURA, R. L. Dynamics of fish assemblages on coral reefs subjected to different managements regimes in the Abrolhos Bank, eastern Brazil. Aquatic Conserv: Mar. Freshw. Ecosys., v. 18, n. 7, p. 11161179, 2008.

FRANCINI-FILHO, R.; MOURA, R. L.; THOMPSON, F. L.; REIS, R. M.; KAUFMAN, L.; KIKUCHI, R. K. P.; LEÃO, Z. M. A. N. Diseases leading to accelerated decline of reef corals in the largest South Atlantic reef complex (Abrolhos Bank, eastern Brazil). Mar. Pol. Bull., v. 56, n. 5, p. 10081014, 2008.

FRANCINI-FILHO, R. B; REIS, R. M.; MEIRELLES, P. M.; MOURA, R. L.; THOMPSON, F. L.; KIKUCHI, R. K. P.; KAUFMAN, L. Seasonal prevalence of whiteplague like disease on the endemic Brazilian reef coral Mussismilia braziliensis. Lat. Amer. J. Aquatic Res., v. 38, n. 2, p. 292296, 2010.

FRANCINI-FILHO, R. B; CONI, E. O. C.; MEIRELLES, P. M.; AMADO-FILHO, G. A.; THOPSON, F. L.; PEREIRAFILHO, G. H.; BASTOS, A. C.; ABRANTES, D. P.; FERREIRA, C. M.; GIBRAN, F. Z.; GÜTH, Z.; SUMIDA, P. Y. G.; OLIVEIRA, N. L.; KAUFMAN, L.; MINTEVERA, C. V.; MOURA, R. L. Dynamics of coral reef benthic assemblages of the Abrolhos Bank, Eastern Brazil: Inferences on natural and anthropogenic drivers. PLoS ONE, v. 8, n. 1, e $54260,2013$.

GASPARINI J. L.; FLOETER S. R.; FERREIRA, C. E. L.; SAZIMA, I. Marine Ornamental Trade in Brazil. Biodiv. Conserv., v. 14, p. 2883-2899, 2005.

GHERARDI, D. F. M.; BOSENCE, D. W. J. Modeling of the ecological sucession of encrusting organisms in recent coralline algal frameworks from Atol das Rocas, Brazil. Palaios, v. 14, n. 2, p. 145-158, 1999.

GHERARDI, D. F. M.; BOSENCE, D. W. J. Composition and community structure of the coralline algal reefs from Atol das Rocas, South Atlantic, Brazil. Coral Reefs, v. 19, n. 3, p. 205219,2001

GHERARDI, D. F. M.; BOSENCE, D. W. J. Late Holocene reef growth and relative sea-level changes in Atol das Rocas, Equatorial South Atlantic. Coral Reefs, v. 24, n. 2, p. 264$272,2005$.

GLYNN, P. W. Widespread coral mortality and the 1982-83 El Niño Warming Event. Environ. Conserv., v. 11, n. 2, p. 133146, 1984.

GLYNN, P. W. Coral reef: bleaching ecological perspectives. Coral Reefs, v. 12, n. 1, p. 1-17, 1993.

GRIGG, R. W.; DOLLAR, S. J. Natural and anthropogenic disturbance on coral reefs. In: DUBINSKY, Z. (org.). Ecosystems of the World Coral Reefs. Amsterdam: Elsevier, 1990. p. 439-452.

GUEST, J. R.; BAIRD, A. H.; MAYNARD, J. A.; MUTTAQIN, E.; EDWARDS, A. J.; CAMPBELL, S. J.; YEWDALL, K.; AFFENDI, Y. A.; CHOU, L. M. Contrasting patterns of coral bleaching susceptibility in 2010 suggest an adaptive response to thermal stress. PLoS ONE, v. 7, n. 3. p. e33353, 2012.

HARTT, C. F. The cruise of the Abrolhos. Amer. Natur., v. 2, p. $86-93,1869$

HARTT, C. F. Geology and physical geography of Brazil. Boston: Boston, Fields, Osgood and Co, 1870. 620 p.
HOEGH-GULDBERG, O. Climate change, coral bleaching and the future of the world's coral reefs. Mar. Fresh Water Res., v. 50, n. 8, p. 839-866, 1999.

HOEGH-GULDBERG, O.; MUMBY, P. J.; HOOTEN, A. J.; STENECK, R.; GLEENFIELD, P.; GOMEZ, E.; HARVELL, C. D.; SALE, P. F.; EDWARDS, A. J.; CALDEIRA, K.; KNOWLTON, N.; EAKIN, C. M.; IGLESIAS-PRIETO, R.; MUTHIGA, N.; BRADBURY, R. H.; DUBI, A.; HATZIOLOS, M. E. Coral reefs under rapid climate change and ocean acidification, Science, v. 318 , n. 5857 , p. 17371742, 2007.

HUGHES, T. P.; BAIRD, A. H.; BELLWOOD, D. R.; CARD, M.; CONNOLLY, S. R.; FOLKE, C.; GROSBERG, R.; HOEGH-GULDBERG, O.; JACKSON, J. B. C.; KLEYPAS, J.; LOUGH, J. M.; MARSHALL, P.; NYSTRON, M.; PALUMBI, S. R.; PANDOLFI, J. M.; ROSEN, B.; ROUGHGARDEN, J. Climate change, human impacts and the resilience of coral reefs. Science, v. 301, n. 5635, p. 929933, 2003.

ILLARI, M. D. T.; SOUZA, A. T.; MEDEIROS, P. R.; GREMPEL, R. G.; SAMPAIO. C. L. S. Recife de Picãozinho: um aquário natural ameaçado. Ciência Hoje, v. 41, p. 71-72. 2007.

JENNINGS, S.; POLUNIN, N. V. C. Impacts of fishing on tropical reef ecosystems. Ambio, v. 25, n. 1, p. 44-49, 1996.

KELMO, F.; ATTRILL, M. J. Cnidarian community structure of coastal reefs from northern Bahia, Brazil. Bull. Mar. Sci., v. 69 , n. 2, p. 547-557, 2001.

KELMO, F.; ATTRILL, M. J.; JONES, M. B. Effects of the 1997/98 El Niño on the cnidarian community of a high turbidity coral reef system (Northern Bahia, Brazil). Coral Reefs, v. 22, n. 4, p. 541-550, 2003.

KIKUCHI, R. K. P.; LEÃO, Z. M. A. N. Rocas (Southwestern Equatorial Atlantic, Brazil): An atoll built primarily by coralline algae. Proc. $8^{\text {th }}$ Intern. Coral Reef. Symp., v. 1, p. 731-736, 1997.

KIKUCHI, R. K. P.; LEÃO, Z. M. A. N. The effects of Holocene sea level fluctuation on reef development and coral community structure, Northern Bahia, Brazil. An. Acad. Bras. Cienc., v. 70, p. 159-171, 1998.

KIKUCHI, R. K. P. Atol das Rocas, Atlântico Sul Equatorial Ocidental, Brasil. In: SCHOBBENHAUS, C.; CAMPOS, D. A.; QUEIROZ, E. T.; WINGE, M.; BERBETBORN, M. (eds.). Sítios Geológicos e Paleontológicos do Brasil. Departamento Nacional de Produção. Mineral-Companhia de Pesquisa de Recursos Minerais, Brasília: SIGEP, 2002. p. 374-390.

KIKUCHI, R. K. P.; LEÃO, Z. M. A. N.; TESTA, V.; DUTRA, L. X. C.; SPANÓ, S. Rapid assessment of the Abrolhos Reefs, Eastern Brazil (Part 1: Stony corals and algae). Atoll Res. Bull., v. 496, p. 172-187, 2003.

KIKUCHI, R. K. P.; LEÃO, Z. M. A. N.; OLIVEIRA, M. D. M. Conservation status and spatial patterns of AGRRA vitality indices in Southwestern Atlantic reefs. Rev. Biol. Trop., v. 58, p. 1-31, 2010.

KIKUCHI, R. K. P.; OLIVEIRA, M. D. M.; LEÃO, Z. M. A. N. Density banding pattern of the South Western Atlantic coral Mussismilia braziliensis. J. Exp. Mar. Biol. Ecol., v. 449, p. 207-214, 2013. 
KRISHNAN, P.; ROY, S. D.; GEORGE, G.; SRIVASTAVA, R. C.; ANAND, A.; MURUGESAN, S.; KALIYAMOORTHY, M.; VIKAS, N.; SOUNDARARAJAN, R. Elevated sea surface temperature during May 2010 induces mass bleaching of corals in the Andaman. Curr. Sci., v. 100, n. 1, p. 111-117, 2011.

KRUG, L. A.; GHERARDI, D. F. M.; STECH, J. L.; LEÃO, Z. M. A. N.; KIKUCHI, R. K. P. Characterization of coral bleaching environments and their variation along the Bahia state coast, Brazil. Int. J. Remote. Sens., v. 33, n. 13, p. 40594074, 2012.

KRUG, L. A.; GHERARDI, D. F. M.; STECH, J. L.; LEÃO, Z. M. A. N.; KIKUCHI R. K. P.; HRUSCHKA JÚNIOR, E. R.; SUGGETT, D. J. The construction of causal networks to estimate coral bleaching intensity. Environ. Model. Softw., v. 42, p. 157-167, 2013.

LABOREL, J. L. A revised list of Brazilian scleractinians corals and descriptions of a new species. Postilla Mus. Nat. Hist. Yale Univ., v. 107, p. 114, 1967.

LABOREL, J. L. Madreporaires et hydrocoralliaires recifaux des côtes brésiliennes. Systematique, ecologie, repartition verticale et geographie. Ann. Inst. Oceanogr., v. 47, p. 171$229,1969$.

LABOREL, J. L. Les peuplements de madreporaires des côtes tropicales du Brésil. Abidjan: Ann. Univ. d'Abidjan, Ser. E, II, Fasc. 3, 1970. 260 p.

LANG, J. C.; MARKS, K. W.; KRAMER, P. A.; KRAMER, P. R.; GINSBURG, R. N. AGRRA, Atlantic and Gulf rapid reef assessment, Protocols Version 5.4. 2010. Cited: 2015 Ago 15. Available at: $<$ http://www.agrra.org $>$.

LEÃO, Z. M. A. N. Abrolhos: o refúgio pleistocênico de uma fauna terciária de corais. Rev. Cienc. Terra, v. 8, p. 22-24, 1983.

LEÃO, Z. M. A. N.; LIMA, O. A. L. Caracterização do substrato de recifes de corais holocênicos a partir de dados de sísmica de refração e perfuração. Rev. Bras. Geocienc., v. 12, p. 531$535,1983$.

LEÃO, Z. M. A. N.; BITTENCOURT, A. C. S. P.; DOMINGUEZ, J. M. L.; NOLASCO, M. C.; MARTIN, L. The effects of Holocene sea level fluctuations on the morphology of the Brazilian coral reefs. Rev. Bras. Geocienc., v. 15, p. 154-157, 1985.

LEÃO, Z. M. A. N.; ARAÚJO, T. M. F.; NOLASCO, M. C. The coral reefs off the coast of eastern Brazil. Proc. $6^{\text {th }}$ Intern. Coral Reef Symp., v. 3, p. 339-347, 1988.

LEÃO, Z. M. A. N. Threats to coral reef environments: In: HETZEL, B.; CASTRO, C. B. (eds.). Corals of Southern Bahia. Rio de Janeiro: Nova Fronteira, 1994. p. 179-181.

LEÃO, Z. M. A. N.; TELLES, M. D.; SFORZA, R.; BULHÕES, H. A.; KIKUCHI, R. K. P. Impact of tourism development on the coral reefs of the Abrolhos area, Brazil: In: GINSBURG, R. N. (eds.). (Compiler), Global Aspects of Coral Reefs: Health, Hazards and History. Miami: Rosenstiel School of Marine and Atmospheric Science, Univ, 1994. p. 254-260.

LEÃO, Z. M. A. N. The coral reefs of Bahia: morphology, distribution and the major environmental impacts. An. Acad. Bras. Cienc., v. 68, p. 439-452, 1996.

LEÃO, Z. M. A. N.; GINSBURG, R. N. Living reefs surrounded by siliciclastic sediments: the Abrolhos coastal reefs, Bahia, Brazil. Proc. $8^{\text {th }}$ Intern. Coral Reef Symp., v. 2, p. 1767-772, 1997.
LEÃO, Z. M. A N.; KIKUCH, R. K. P. The Bahian coral reefs from 7000 years BP to 2000 years AD. Ci. Cult. J. Braz. Ass. Adv. Sci., v. 51, n. 3/4, p. 262-273, 1999.

LEÃO, Z. M. A. N.; KIKUCHI, R. K. P.; MAIA, M. P.; LAGO, R. A. L. A catastrophic coral cover decline since 3,000 years BP, Northern Bahia, Brazil. International Coral Reef Symposium, 8. Proceedings., v. 1, p. 583-588, 1997.

LEÃO, Z. M. A. N.; KIKUCHI, R. K. P. the Abrolhos Reefs of Brasil. In: SEELIGER, U.; KJERFVE, B. (Eds.). Coastal marine ecosystems of Latin America, ecological studies. Berlin: Springer-Verlag, 2001. p. 83-96.

LEÃO, Z. M. A. N.; KIKUCHI, R. K. P.; TESTA, V. Corals and coral reefs of Brazil, In CORTES J. (ed.). Latin American Coral Reefs. Amsterdam: Elsevier Publisher, 2003. p. 9-52.

LEÃO, Z. M. A. N.; KIKUCHI, R. K. P. A relic coral fauna threatened by global changes and human activities, Eastern Brazil. Mar. Pollut. Bull., v. 51, p. 599-611, 2005.

LEÃO, Z. M. A. N.; KIKUCHI, R. K. P.; DUTRA, L. X. C.; OLIVEIRA, M. D. M. The status of Eastern Brazil coral reefs during the last 5000 years. Proc. $10^{\text {th }}$ Int. Coral Reef Symp., v.1, p. 959-968, 2006.

LEÃO, Z; M. A. N.; FOURNIER, J. Contribution à l'étude biogéomorphologique d'un archipel d'origine volcanique: une synthèse sur le complexe récifal d'Abrolhos (Bahia, Brésil). In: ÉTIENNE, S.; PARIS, R. (Orgs.). Les littoraux volcaniques: Une approche environnementale. ClermontFerrand: Presses Universitaires Blaise Pascal, 2007. p. 193219.

LEÃO, Z. M. A. N.; KIKUCHI, R. K. P.; OLIVEIRA, M. D. M. Branqueamento de corais nos recifes da Bahia e sua relação com eventos de anomalias térmicas nas águas superficiais do oceano. Biota Neotropica., v. 8, n. 3, p. 69-82, 2008.

LEÃO, Z. M. A. N.; KIKUCHI, R. K. P.; AMARAL, F. M. D.; OLIVEIRA, M. D. M.; COSTA, C. F. Recifes de Corais: Tesouros agonizantes. Sci. Am. Brasil., v. 3, p. 74-82, 2009.

LEÃO, Z. M. A. N.; KIKUCHI, R. K. P.; OLIVEIRA, M. D. M.; VASCONCELLOS, V. Status of Eastern Brazilian coral reefs in time of climate changes. Panam. J. Aquat. Sci., v. 5, n. 2, p. 224-235, 2010.

LEÃO,Z.M.A.N.,AUGUSTOMINERVINO-NETO,BEATRICE P. FERREIRA, CAROLINE V. FEITOSA, CLAUDIO L. S. SAMPAIO, CRISTIANE F. COSTA-SASSI, ELIZABETH G. NEVES, FÚLVIO A. M. FREIRE, GEORGE-OLAVO M. SILVA, GIL M. R. STRENZEL, HILDA H. SOVIERZOSKI, JORGE E. L. OLIVEIRA, LIANA F. MENDES, MARCELO O. SOARES, MARIA-ELISABETH ARAUJO, MARÍLIA D. M. OLIVEIRA, MAURO MAIDA, MONICA D. CORREIA, RICARDO S. ROSA, ROBERTO SASSI, RODRIGO JOHNSSON, RONALDO B. FRANCINI-FILHO, RUY K. P. KIKUCHI, TATIANA S. LEITE. Monitoramento dos recifes e ecossistemas coralinos. In: TURRA, A.; DENADAI, M. R. Protocolos de campo para o monitoramento de habitats bentônicos costeiros p. 155-179. Instituto Oceanográfico da Universidade de São Paulo, 2015.

MAIDA, M.; FERREIRA, B. P.; BELLINI, C. Avaliação preliminar do recife da Baía do Sudeste, Fernando de Noronha, com ênfase nos corais escleractíneos. Bol. Tec. Cient., v. 3, p. 37-47, 1995.

MAIDA, M.; FERREIRA, B, P. Coral reefs of Brazil: an overwiew. Proc. $8^{\text {th }}$ Int. Coral Reef Symp., v.1, p. 263-274, 1997. 
MAIDA, M.; FERREIRA, B. P. Área de Proteção Ambiental Costa dos Corais. In: PRATES, A. P. L. (ed.). Atlas dos recifes de coral nas unidades de conservação brasileiras. Brasília: Ministério do Meio Ambiente, 2003. p. 86-90.

MANTELATTO, M. C.; CREED, J. C.; MOURÃO, G. G.; MIGOTTO, A. E.; LINNDNER, A. Range expansion of the invasive corals Tubastraea coccinea and Tubastraea tagusensis in the Southwest Atlantic. Coral Reefs, v. 30, n. 2, p. 397, 2011.

MARTIN, L.; FLEXOR, J. M.; VILAS BOAS, G. S.; BITTENCOURT, A. C. S. P.; GUIMARÃES, M. M. M. Courbe de variations du niveau relatif de la mer au cours des 7000 derniers années sur un secteur hmogene du litoral brésilien (nord de SalvadorBahia). Proc. Inter. Symp. Coastal Evol. Quaternary, v. 1, p. 264-274, 1979.

MARTIN, L.; FLEXOR, J. M.; BLITZKOW, D.; SUGUIO, K. Geoid change indications along the Brazilian coast during the last 7,000 years. InternationaL CORAL Reef Symposium, 5. Proceedingsâ, v. 3, p. 85-90, 1985.

MARTIN, L.; SUGUIO, K.; FLEXOR, J. M.; DOMINGUEZ, J. M. L.; BITTENCOURT, A. C. S. P. Quaternary sealevel history and variation in dynamics along the central Brazilian coast: consequences on coastal plain construction. An. Acad. Bras. Cienc., v. 68, p. 303-354, 1996.

MAŸAL, E. M. Mercado de Corais. Rev. Ciência Hoje, v. 5, p. 43, 1986

MAŸAL, E. M.; BEZERRA, B. Situação atual dos corais do Atol das Rocas. Biológica Brasílica, v. 6, p. 77-80, 1995.

MIGOTTO, A. E. Anthozoa bleaching on the southeastern coast of Brazil in the summer of 1994. Proc. $6^{\text {th }}$ Inter. Conf. Coelenterate Biol., p. 329-335, 1995.

MIGOTTO, A. E.; SILVEIRA, S. L.; SCHLENZ, E.; FREITAS, J. C. Filo Cnidaria. In: MIGOTTO, A. E.; THIAGO, C. G. (eds.). Bases para conservação da biodiversidade de São Paulo - Síntese do conhecimento ao final do século XX 3: invertebrados marinhos. Biodiversidade do Estado de São Paulo: São Paulo: FAPESP, 1999. p. 33-46.

MILOSLAVICH, P.; KLEIN, E.; DÍAZ, J. M.; HERNÁNDEZ, C. E.; BIGATTI, G.; CAMPOS, L.; TIGAS, F.; CATILLO, J.; PENCHASZADEH, P. E.; NEIL, P. E.; CARRANZA, A.; RETANA, M.V.; DÍAZ DE ASTARLOA, J.M.; LEWIS, M.; YORIO, P.; PIRIZ, M. L.; RODRÍGUEZ, D.; YONESHIGUE-VALENTIN, Y.; GAMBOA, L.; MARTIN, A. Marine biodiversity in the Atlantic and Pacific coasts of South America: knowledge and Gaps. PLoS ONE, v. 6, n. 1, p. e14631, 2011.

MIRANDA, R. J.; PORTO, L.; CRUZ, I. C. S. BARROS, F. Coral invasor Tubastraea spp. em recifes de corais e substratos artificiais na Baía de Todos os Santos (BA). An. Congr. Bras. Ocean., p. 1527-1532, 2012.

MIRANDA, R. J.; CRUZ, I. C. S.; LEÃO, Z. M. A. N. Coral bleaching in the Caramuanas reef (Todos os Santos Bay, Brazil) during the 2010 El Niño event. Lat. Am. J. Aquat. Res., v. 41, n. 2, p. 351-360, 2013.

MOBERG, F.; FOLKE, C. Ecological goods and services of coral reef ecosystems. Ecolog. Econ., v. 29, p. 215-233, 1999.

MOBERG, F.; RÖNNBÄCK, P. Ecosystem services of the tropical seascape: Interactions, substitutions and restoration. Ocean. Coastal Manag., v. 46, n. 1/2, p. 27-46, 2003.
MOURA, R. L.; SECCHIN, N. A.; AMADO-FILHO, G. M.; FRANCINI-FILHO, R. B.; THOMPSON, F. L.; SUMIDA, P. Y.; GUTH, A. Z., BASTOS, A. C.; MINTE-VERA, C. V.; DUTRA, G. F.; LOPES, R. M.; FREITAS, M. O. Spatial patterns of benthic megahabitats and conservation planning in the Abrolhos Bank. Cont. Shelf Res., v. 70, p. 109-117, 2013.

MULLER-PARKER, G.; D'ELIA, S. F. Interactions between corals and their symbiotic algae. In: BIKERLAND, C. (Ed.) Life and Death of Coral Reefs. New York: Chapman and Hall, 1997. p. 96-113.

NEVES, E. G.; JOHNSSON, R.; SAMPAIO, C. L. Note on the occurrence of Scolymia cubensis (Cnidaria, anthozoa, Scleractinia) in Brazil. Anais II Congr. Bras. Oceanogr., p. 12, 2005.

NEVES, E. G.; JONHSSON, R.; SAMPAIO, C. L.; PICHON, M. The occurrence of Scolymia cubensis in Brazil: revising the problem of the Caribbean solitary mussids. Zootaxa, v. 1366, p. 45-54, 2006.

NEVES, E. G.; ANDRADE, S. C. S.; SILVEIRA, F. L.; SOLFERINI, V. N. Genetic variation and population structuring in two brooding coral species (Siderastrea stellata and Siderastrea radians) from Brazil. Genetica, v. 132, p. 243-254, 2008.

NEVES, E. G.; SILVEIRA, F. L.; PICHON, M.; JOHNSSON, R. Cnidaria, Scleractinia, Siderastreidae, Siderastrea siderea (Ellis and Solander, 1786): Hartt Expedition and the first Record of a Caribbean siderastreid in tropical Southwestern Atlantic. Check List, v. 6, n. 4, p. 505- 510, 2010.

NOLASCO, M. C.; LEÃO, Z. M. A. N. The carbonate buildups along the Northern coast of the State of Bahia, Brazil. In: RABASSA, J. (Ed.). Quaternary of South America and Antarctic Peninsula. Rotterdam: Balkema Pub, 1986. p. 159-190.

OIGMAN-PSZCZOL, S. S.; CREED, J. C. Size structure and spatial distribution of the corals Mussismilia hispida and Siderastrea stellata (Scleractinia) at Armação dos Búzios, Brazil. Bull. Mar. Sci., v. 74, n. 2, p. 433-448, 2004.

OIGMAN-PSZCZOL, S. S.; CREED, J. C. Distribution and abundance of fauna on living tissues of two Brazilian hermatypic corals (Mussismilia hispida (Verril 1902) and Siderastrea stellata Verril, 1868). Hydrobiologia, v. 563, p. 143-154, 2006.

OLIVEIRA, M. D. M.; LEÃO, Z. M. A. N.; KIKUCHI, R. K. P. Sinais do aquecimento global em Abrolhos, Bahia: Um estudo com o coral Mussismilia braziliensis (Verrill, 1868). Anais XII Congr. Latino-Americano Cienc. Mar., p. 13, 2007.

OXENFORD, H. A.; ROACH, R.; BRAITHWAITE, A. Large scale coral mortality in Barbados: a delayed response to the 2005 bleaching episode. Proc. $11^{\text {th }}$ Intern. Coral. Reef Symp., p. 505-509, 2010.

PAULA, A. F.; CREED, J.C. Spatial distribution and abundance of nonindigenous coral genus Tubastraea (Cnidaria, Scleractinia) around Ilha Grande, Brazil. Bras. J. Biol., v. 65, p. 661-673, 2005.

PANDOLFI, J. M.; JACKSON, J. B. C.; BAON, N.; BRADBURRY, R. H.; GUZMAN, H. M.; HUGHES, T. P.; KAPPEL, C. V.; MICHELI, F.; OGDEN, J. C.; POSSINGHAM, H. P.; SALA, E. Are US Coral reefs on the slippery slope in slime? Science, v. 307, p. 1725-1726, 2005. 
PEREIRA, N. S.; MANSO, V. A. V.; SILVA, A. M. C.; SILVA, M. B. Mapeamento geomorfológico e morfodinâmico do Atol das Rocas, Atlântico Sul. Rev. Gest. Cost. Integ., v. 10, n. 3, p. 331-345. 2010.

PIRES, D. O.; CASTRO, C. B.; MIGOTTO, A. Benthic cnidária of Fernando de Noronha Archipelago, Brazil. Bul. Mus. Nac., v. 354, p. 121,1992

PITOMBO, F.; RATTO, C. C.; BELÉM, M. J. C. Species diversity and zonation pattern of hermatypic corals at two fringing reefs of Abrolhos Archipelago, Brazil. Proc. $6^{\text {th }}$ Int. Coral Reef Symp., v. 2, p. 817-820, 1988.

PRATES, A. P. L.; PEREIRA, P. M. Representatividade das unidades de conservação costeiras e marinhas: análise e sugestão. Anais, $2^{\circ}$ Congresso Brasileiro de Unidades de Conservação. Campo Grande: Brasil, 2000. p. 784-793.

PRATES, A. P. L.; PEREIRA, P. M.; HAZIN, M. C.; REINHARDT, M. H.; FERREIRA, B. P.; MAGALHÃES, A. E. Campanha de Conduta Consciente em Ambientes Recifais. Anais, $3^{\circ}$ Congresso Brasileiro de Unidades de Conservação. Fortaleza: Brasil, 2002. p. 423-432.

PRATES, A. P. L. Unidades de Conservação. In: PRATES, A. P. L. (Org.). IBAMA - Atlas dos Recifes de Corais nas Unidades de Conservação Brasileiras. 2. ed. Brasília: Ibama, 2006. $232 \mathrm{p}$.

REIS, M. A. C.; LEÃO, Z. M. A. N. Bioerosion rate of the sponge Cliona celata (Grant 1826) from reefs in turbid waters, North Bahia, Brazil. Proc. $8^{\text {th }}$ Int. Coral Reef Symp., v. 1, p. 273-278, 2003.

RIUL, P.; TARGINO, C. H.; JÚNIOR, L. A. C.; CREED, J. C.; HORTA, P. A.; COSTA, G. C. Invasive potential of the coral Tubastraea coccinea in the southwest Atlantic. Mar. Ecol. Prog. Ser., v. 480, p. 73-81, 2013.

ROBERTS, C. M. Effects of fishing on the ecosystem structure of coral reefs. Conserv. Biol., v. 9, p. 988-995, 1995.

RODRÍGUEZ-RAMÍREZ, A.; BASTIDAS, C.; CORTÉS, J.; GUZMÁN, H.; LEÃO, Z.; GARZÓN-FERREIRA, J.; KIKUCHI, R.; FERREIRA, B. P.; ALVARADO, J. J.; JIMÉNEZ, C.; FONSECA, A. C.; SALAS, E.; NIVIA, J.; FERNÁNDEZ, C.; RODRÍGUEZ, S.; DEBROT, D.; CRÓQUER, A.; GIL, D.; GÓMEZ, D. I.; RAÚL NAVASCAMACHO, R.; REYS-NIVIA, M. C.; ACOSTA, A.; ALVARADO, E.; PIZARRO, V.; SANJUAN, A.; HERRON, P.; ZAPATA, F. A.; ZEA, S.; LÓPEZ-VICTORIA, M.; SÁNCHEZ, J. A. Status of coral reefs and associated ecosystems in Southern Tropical America: Brazil, Colombia, Costa Rica, Panama and Venezuela. In: WILKSON, C. (eds.). Status of Coral Reefs of the World 2008. Global Coral Reefs Monitoring Network (GCRMN). Australia: Townsville, 2008. p. 281-294.

SALVAT, B. Coral reefs - a challenging ecosystem for human societies. Global. Environ. Chang., v. 2, n.1, p. 12-18, 1992.

SAMPAIO, C. L. S.; MIRANDA, R. J.; MAIA-NOGUEIRA, R.; NUNES, J. A. C. New occurrences of the nonindigenous orange cup corals Tubastraea coccinea and T. tagusensis (Scleractinia: Dendrophyliidae) in Southwestern Atlantic. Check List, v. 8, n. 3, p. 528-530, 2012.

SANTA-IZABEL, L. M.; LEÃO, Z. M. A. N.; PESO-AGUIAR, M. C. Polychaetes from the Guarajuba coral reefs, Bahia, Brazil. Bull. Mar. Sci., v. 67, n. 1, p. 645-653, 2000.
SANTOS, C. L. A.; VITAL, H.; AMARO, V. E.; KIKUCHI, R. K. P. Mapeamento de recifes submersos na costa do Rio Grande do Norte, NE Brasil: Macau a Maracajau. Rev. Bras. Geof., v. 25, n. 1, p. 27-35, 2007.

SEGAL, B.; EVANGELISTA, H.; KAMPEL, M.; GONÇALVES, A. C.; POLITO, P. S.; SANTOS, E. A. Potential impacts of polar fronts on sedimentation processes at Abrolhos coral reefs (South-West Atlantic Ocean, Brazil). Cont. Shelf Res., v. 28, n. 4 , p. 533-544, 2008.

SEGAL, B.; CASTRO, C. B. Coral community structure and sedimentation at different distances from the coast of the Abrolhos Bank, Brazil. Bras. J. Oceanogr., v. 59, n. 2, p. 119$129,2011$.

SILVA, A. S.; LEÃO, Z. M. A. N.; KIKUCHI, R. K. P.; COSTA, A. B.; SOUZA, J. R. B. Sedimentation in the coastal reefs of Abrolhos over the last decades. Cont. Shelf Res., v. 70, n. 1, p. 159-167, 2013.

SOARES, M. O.; LEMOS, V. B.; KIKUCHI, R. K. P. Aspectos biomorfológicos do Atol das Rocas, Atlântico sul Equatorial. Rev. Bras. Geoc., v. 41, n. 1, p. 85-94, 2011a.

SOARES, M. O.; MEIRELLES, C. A. O.; LEMOS, U. B. Reef bioconstructors of Rocas Atol, Equatorial South Atlantic. Biotemas, v. 24, p. 37-46, 2011 b.

SOARES, M. O.; RABELO, E.F. Primeiro registro de branqueamento de corais no litoral do Ceará (NE, Brasil): indicador das mudanças climáticas? Geociências, v. 33, p. $1-10,2014$.

SPALDING, M. D.; GRENFELL, A. M. New estimates of global and regional coral reef areas. Coral Reefs, v. 16, n. 4, p. 225230, 1997.

SPANÓ, S.; LEÃO, Z. M. A. N.; KIKUCHI, R. K. P. Diagnóstico do estado de conservação dos recifes em franja do Parque Nacional Marinho dos Abrolhos. OLAM: Cienc. Tecnol., v. 8 , n. 2, p. 245-277, 2008.

SPURGEON, J. P. G. The economic valuation of coral reefs. Mar. Pollut. Bull., v. 24, n. 11, p. 529-536, 1992.

STEINER, A. Q.; ELOY C. C.; AMARAL, J. R. B. C.; AMARAL, F. M. D.; SASSI, R. O turismo em áreas de recifes de coral: considerações acerca da Área de Proteção Ambiental Costa dos Corais (Estados de Pernambuco e Alagoas). OLAM: Cienc. Tecnol., v. 6, n. 2, p. 281-296, 2006.

TESTA, V. Calcareous algae and corals in the inner shelf of Rio Grande do Norte, NE Brazil. Proc. $8^{\text {th }}$ Int. Coral Reef Symp., v. 1, p. $737-742,1997$.

VASKES JÚNIOR, T.; LESSA, R.; NÓBREGA, M. F.; AMARAL, F. M. D. ; SILVEIRA, S. R. M.; ASSIS, F. Arquipélago de São Pedro e São Paulo: Histórico e Recursos naturais. Fortaleza: LABOMAR, 2010. 242 p.

VILLAÇA, R.; PITOMBO, F. B. Benthic communities of shallowwater reefs of Abrolhos, Brazil. Rev. Bras. Oceanogr., v. 45, n. $1 / 2$, p. $35-43,1997$.

VERRILL, A. E. Notes of the radiates in the Museum of Yale College, with descriptions of new genera and species. 4 . Notes of the corals and echinoderms collected by Prof. C. F. HARTT at the Abrolhos reefs, Province of Bahia, Brazil. Conn. Acad. Arts Sci. Transact., v. 1, n. 2, p. 351-371, 1868.

VERRILL, A. E. Variations and nomenclature of Bermudian, West Indian and Brazilian reef corals with notes on various Indo Pacific corals. Conn. Acad. Arts Sci. Transact., v. 11, p. 63-168, 1901. 
VERRILL, A. E. The gorgonians of the Brazilian coast. J. Acad. Nat. Sci., v. 2, p. 373-404, 1912.

WILKINSON, C. \& SOUTER, D. 2008. Status of Caribbean coral reefs after bleaching and hurricanes in 2005. Global Coral Reef Monitoring Network - GCRMN. Australian Institute of Marine Science, Townsville, p. 3-13.

WILKINSON, C. Status of coral Reefs in the World 2000. Townsville: Australian Institute of Marine Science and the Global Coral Reef Monitoring Network, 2000. 363 p.
WILKINSON, C. Status of Coral Reefs in the World 2002. Townsville: Australian Institute of Marine Science and the Global Coral Reef Monitoring Network, 2002. 378 p.

WILKINSON, C. Status of Coral Reefs in the World 2004. Townsville: Australian Institute of Marine Science and the Global Coral Reef Monitoring Network, 2004. 553 p.

WILKINSON, C. Status of coral reefs of the world: 2008. Global Coral Reef Monitoring Network and Reef and Rainforest Research Centre, Townsville, Australia, 296 p. 
